\title{
Pueblo, constitución y cambio ${ }^{1}$
}

People, constitution and change

Pessoas, constituição e mudança

Peuple, constitution et changement

\section{Raúl Gustavo Ferreyra ${ }^{2}$ Universidad de Buenos Aires}

Revista Derechos en Acción

Año 3/No 9 Primavera 2018, 33-120

DOl: https://doi.org/10.24215/25251678e215

ORCID: https://orcid.org/0000-0001-5089-8136

Recibido: 17/09/2018

Recibido con modificaciones: 29/11/2018

Aprobado: 01/12/2018

Resumen: El poder ciudadano constituyente puede construir una comunidad. Dicho poder reside en la participación libre de ciudadanos iguales, que sean capaces de decidir y discernir sobre los programas y elegir a la luz del día, en comicios auténticos, quienes han de ser sus representantes políticos que fundarán o cambiarán la norma suprema de la comunidad que propicia su existencia y cognición. La producción democrática de la Constitución, aunque caracteriza su naturaleza ineludible respecto de la parición jurídica, no presupone -ni mucho menos- una ciudadanía enteramente democrática en su ejercicio, aplicación o realización. La experiencia demuestra significativos actos de crueldad con los enunciados imperativos del poder constituyente originario. Por eso, el abuso de poder, bajo cualquier forma (prohibir elecciones, prohibir la protesta, anular o menguar la división de poderes, evitar el debate congresual, impedir la libertad de expresión, perseguir por vía jurisdiccional -sin fundamentos- a ciudadanos opositores, desfinanciar los partidos políticos,

1 Dedicado al Prof. Dr. Paulo Bonavides, jurista eminente y decano de las letras jurídicas en América del Sud.

2 Abogado. Profesor titular Derecho constitucional, Facultad de Derecho, Universidad de Buenos Aires (UBA). Doctor de la Universidad de Buenos Aires. Post doctor en Derecho, Facultad de Derecho (UBA). rgferreyra@derecho.uba.ar 
legislar o determinar políticas públicas por intermedio de la jurisdicción, proscripción política, etc.), supone actuaciones contra la democracia que desgarran cualquier posibilidad de edificación de la ciudadanía; en otras palabras: el negacionismo de una ciudadanía democrática. Negar el ejercicio del poder ciudadano puede constituir una verdadera catástrofe y el desguace del Estado Constitucional.

Palabras claves: Ciudadano; Poder; Estado constitucional; Cambio jurídico; Abuso del Poder.

Abstract: Constituent citizen power can build a community. Such power resides in the free participation of equal citizens, who are capable of deciding and discerning about programs and choosing in the light of day, in authentic elections, who must be their political representatives who will found or change the supreme norm of the community that fosters their existence and cognition. The democratic production of the Constitution, although it characterizes its unavoidable nature with respect to juridical parition, does not presuppose - much less - an entirely democratic citizenship in its exercise, application or realization. Experience shows significant acts of cruelty to the imperatives of original constituent power. Therefore, the abuse of power, in any form (prohibiting elections, prohibiting protest, nullifying or diminishing the division of powers, avoiding congressional debate, preventing freedom of expression, pursuing opposition citizens by jurisdictional means -without foundations-, definancing political parties, legislating or determining public policies through jurisdiction, political proscription, etc.), implies actions against democracy that tear at any possibility of building citizenship; in other words: the negationism of a democratic citizenship. Denying the exercise of citizen power can constitute a true catastrophe and the dismantling of the Constitutional State

Keywords: Citizen; Power; Constitutional State; Juridical Change; Abuse of Power.

Resumo: 0 poder cidadão constituinte pode construir uma comunidade. Esse poder reside na livre participação de cidadãos iguais, capazes de decidir e discernir sobre os programas e escolher à luz do dia, em comícios autênticos, quem devem ser seus representantes políticos que fundarão ou mudarão a norma suprema da comunidade que propicia sua existência e cognição. A produção democrática da Constituição, embora 
caracterize sua natureza inevitável em relação ao nascimento jurídico, não pressupõe - muito menos - uma cidadania inteiramente democrática em seu exercício, aplicação ou realização. A experiência demonstra atos significativos de crueldade com as declarações imperativas do poder constituinte originário.Portanto, o abuso de poder, em qualquer forma (proibir eleições, proibir protestos, anular ou diminuir a divisão de poderes, evitar o debate no Congresso, impedir a liberdade de expressão, perseguir judicialmente -sem fundamento- cidadãos opositores, desfinanciamento os partidos políticos, legislar ou determinar políticas públicas através da jurisdição, proscrição política, etc.), supõe ações contra a democracia que rasguem qualquer possibilidade de edificação da cidadania; em outras palavras: o negacionismo de uma cidadania democrática. Negar o exercício do poder cidadão pode constituir uma verdadeira catástrofe e o desmantelamento do Estado constitucional.

Palavras-chave: Cidadão. Poder. Estado constitucional. Muda jurídica. Abuso de poder

Résumé: Le pouvoir constituant des citoyens peut construire une communauté. Ce pouvoir réside dans la libre participation de citoyens égaux, capables de décider et de discerner les programmes et de choisir à la lumière du jour, a travers élections authentiques, ceux qui doivent être leurs représentants politiques, ceux qui fonderont ou modifieront la loi suprême de la communauté, cela qui favorise son existence et sa connaissance. La production démocratique de la Constitution, même si elle caractérise son caractère incontournable en ce qui concerne la naissance légale, ne présuppose pas - et encore moins - une citoyenneté entièrement démocratique dans son exercice, son application ou sa réalisation. L'expérience montre des actes importants de cruauté avec les déclarations impératives du pouvoir constituant originaire. Par conséquent, l'abus de pouvoir, sous n'importe quelque forme que ce soit (interdire les élections, interdire les manifestations, annuler ou réduire la division des pouvoirs, éviter les débats au Congrès, entraver la liberté d'expression, poursuivre en justice des citoyens opposants sans motif, l'interruption ou diminution du financement de partis politiques, la légalisation ou la détermination de politiques publiques par la juridiction, l'interdiction politique, etc.), supposent des actions contre la démocratie qui déchirent toute possibilité d'édification de la citoyenneté; autrement dit: le déni d'une citoyenneté démocratique. La négation de l'exercice du pouvoir 
citoyen peut constituer une véritable catastrophe et le démantèlement de l'État constitutionnel.

Mot-clés: Citoyen, Pouvoir; Etat constitutionnel; Changement juridique; Abus de pouvoir

El coronel no leyó los titulares. Hizo un esfuerzo para reaccionar contra su estómago. "Desde que hay censura los periódicos no hablan sino de Europa», dijo. "Lo mejor será que los europeos se vengan para acá y que nosotros nos vayamos para Europa. Así sabrá todo el mundo lo que pasa en su respectivo país.» - Para los europeos América del Sud es un hombre de bigotes, con una guitarra y un revólver - dijo el médico, riendo sobre el periódico-. No entienden el problema. GARCÍA MÁRQUEZ, Gabriel: El coronel no tiene quien le escriba, Editorial La Oveja Negra, Bogotá, $5^{\text {a }}$ edición colombiana, Bogotá, 1981, p. 24.

La América del Sud es a la vez rica y miserable. Es rica por la manera de ser de su suelo. Es pobre por el modo de ser de su pueblo. La riqueza propiamente tal es la obra combinada del suelo y del hombre. Por rico que un territorio sea, el pueblo que lo habita será pobre si no sabe sacar de su seno la riqueza que contiene en germen por la obra de su trabajo inteligente y enérgico. Enseñar al pueblo a crear la riqueza es enseñarle a ser fuerte y libre. La riqueza es poder y libertad; y el autor de su riqueza es uno mismo. En esa enseñanza consiste la parte principal de su educación por el presente. Esa es la educación que el pueblo de Sudamérica necesita y no recibe.

ALBERDI, Juan Bautista: Escritos póstumos (Estudios económicos), Buenos Aires, Imprenta Europea, 1895, p. 499. 


\section{$\S$ I. Contexto}

La construcción del constitucionalismo dentro de los Estados sudamericanos, en pleno siglo xxI, constituye una tarea cotidiana que se enlaza con la organización democrática en garantía de la paz. Los órdenes jurídicos de cada uno de los Estados de América del Sud (subcontinente con más de 18.000.000 kilómetros cuadrados de superficie y más de 400.000 .000 de habitantes) disponen de un escalonamiento jerárquico y emplazan a la Constitución como base; un instrumento indisponible del sistema de fuentes, porque se trata de un bien colectivo de la ciudadanía.

El Derecho constituyente de cada uno de los Estados de América del Sud contiene, en la actualidad, casi todas las definiciones conocidas en el comparatismo constitucionalista mundial. Si se compilaran las Constituciones sudamericanas en vigencia, cuyo resultado se expresaría en más de 1.500 páginas de enunciados normativos y no normativos, se descubriría que casi todo ha sido concebido en esta parte del mundo. Las excepciones pueden ser agrupadas en cuatro carencias notorias: a) la consolidación de un sistema de gobierno parlamentario; b) mecanismos de controles racionales, cruzados y efectivos para evitar la desmesura del Poder Ejecutivo; $c$ ) un control de constitucionalidad no jurisdiccional y preventivo, o un control de constitucionalidad jurisdiccional cuya última palabra reposare en el Congreso, Asamblea o cuerpo electoral; y $d$ ) la posibilidad de transferencia o cesión de competencias soberanas a instituciones interestatales con nivel semejante a la Constitución.

Luego de 200 años, desde la independencia del yugo colonial europeo, la ordenación constitucional, en cada uno de estos países, exhibe un momento de notable riqueza conceptual. América del Sud no necesitaría importar doctrinas o dogmas constitucionalistas. Tampoco se debería copiar jurisprudencia, ni siquiera fórmulas laberínticas que, atractivas donde son producidas y vulgarizadas, dejan de serlo por las propiedades congénitas de nuestra indisimulable e irreversible situación 
periférica respecto de los centros de poder mundialmente globalizados (EE. UU., Europa y China: verdaderos núcleos de la economía y las finanzas del mundo).

Esta condición ubica a los sudamericanos en una paradigmática lucha por el Derecho a nivel mundial, lucha que debería orientarse a concretar una aspiración mínima: invertir el hecho de que el actual modelo de sociedad incorpora a una minoría de la población y hace que la mayoría absoluta de las personas humanas que habitan las comunidades queden "estructural y definitivamente excluidas"3. La referencia, desde luego, amerita a los sujetos naturales desposeídos: pobres y vulnerables.

No es mi intención hacer un proyecto jurídico de "Estado constitucional" para el subcontinente. Juzgo que debe distinguirse el capital jurídico que se conjuga en todas y cada una de las leyes fundamentales. Tal conocimiento fomenta hoy, sin dudas, la realización de una dogmática constitucional, de cuño sudamericana, tan propia como apropiada. Si la filosofía en la Grecia antigua despertó, hace más de 25 siglos, en el mismo momento que un hombre preguntó por otro hombre que había sentado a su lado, antes que la observación o contemplación de la naturaleza, entonces la alteridad de la existencia contemporánea nos obliga a pensar y repensar, también, a cada uno de los sudamericanos, sentado uno al lado del otro, dentro de los límites generosos de nuestro subcontinente. "Nos obliga" -sostengo- a proponer nuestro propio, único, exclusivo y excluyente pensamiento jurídico-constitucional, que con fuertes rasgos de inclusión cultural, social, económica y política, signifique el punto de partida de un constitucionalismo de ciudadanos. La inclusión ciudadana, en rechazo indeclinable a cualquier modelo de exclusión, debería ser el faro del desarrollo constitucionalista.

Me concentro en este estudio en un fragmento del Derecho constitucional positivo vigente en América del Sud: no pretendo

3 ZafFARoni, E. Raúl: "Estado gendarme o Estado fraterno", en La Tecl@ Eñe Revista de Cultura y Política, disponible en https://lateclaenerevista.com/2018/01/18/estado-gendarmeo-estado-fraterno/, consultado por última vez el 10/7/2018. 
ni mucho menos glorificar el ejercicio de la función narrativa al elegir a la República de Colombia, con su territorio de casi 1.200.000 kilómetros cuadrados y su población cercana a los 50.000.000 de seres humanos.

La República de Colombia tiene fundamentos "elaborados" ${ }^{4}$, sobrios y apropiados en su texto constitucional en vigor, nacido en 1991, para fundar la paz, entendida como una edificación perenne de los seres humanos 5 . El ámbito de la escritura se refiere principalmente a Colombia, dentro del marco de ordenación prescrito por la Constitución Política de 1991 (en adelante, CPC 1991). Sin embargo, espero que pueda ser útil para desarrollar, genuinamente, inferencias que más temprano que tarde sean susceptibles de tipificar aspectos sobre la "identidad" del Derecho constitucional comparado en América del Sud. Por consiguiente, dentro del contexto sudamericano y en su seno -el subcontexto colombiano- estoy decidido, aquí, a describir y justificar la siguiente "tesis primitiva":

4 V. Marquardt, Bernd: Los dos siglos del Estado constitucional en América Latina (18102010). Historia constitucional comparada, t. 2, Bogotá, Universidad Nacional de Colombia, 2011, p. 303.

5 En este ensayo, el término "ser humano" se utiliza con igual significado al de "persona natural" o "persona humana" o "persona" o "sujeto natural". Independientemente de los campos semánticos que estos términos puedan llegar a tener, sigo, con firmeza y no menor dosis de terquedad dogmática, el enunciado ecuménico prescrito en la Convención Americana sobre Derechos Humanos (1969), art. 1 (Obligación de respetar los derechos), ap. 2: "Para los efectos de esta Convención, persona es todo ser humano". Además, justifico de antemano que, al apelar a "persona humana" o "persona natural" en el mismo sentido que "persona", aunque prima facie pareciera sobreabundante a partir de lo antedicho, no lo es, en tanto y en cuanto se repute que lo hago para despejar cualquier sospecha que el lector pudiese tener o imaginar sobre "personas artificiales", entidades ideales, cuya ficción resulta siempre fundada, fecundamente, por el Derecho. Como se aprecia más adelante, en la sección § III, las personas naturales o humanas son las fundadoras del Derecho y no dependen, jamás, de su fecundidad para existir. También existen normas que preexistentes al bautismo jurídico de la Convención. Destaco dos enunciados que se han erigido, históricamente, en un sostén de la dignidad y la igualdad jurídica de los seres humanos: i) el art. 1 de la Declaración de los Derechos del Hombre y del Ciudadano (1789), "Los hombres nacen y permanecen libres e iguales en derechos"; y ii) el artículo 6 de la Declaración Universal de Derechos Humanos (ONU, 1948), “Todo ser humano tiene derecho, en todas partes, al reconocimiento de su personalidad jurídica". La CPC 1991 se ha inscrito en la aludida canonización del ser humano. En el art. 14 se dispone que: "Toda persona tiene derecho al reconocimiento de su personalidad jurídica". 
La dirección suprema de la ordenación estatal debe residir en los ciudadanos que integran el pueblo, quienes, por lo general, poseen ideas diversas y muchas veces no coincidentes. La ejercen por representación (intermediada siempre por el sufragio y el representante) u, ocasionalmente, en forma directa. En sentido formal, un ciudadano es un elector, porque puede participar en la producción de la suma regla, a condición de que sea convocado y se confiera reconocimiento a determinados derechos básicos. Pese a la inexistencia del mandato imperativo, la ilusión de la democracia directa lleva a considerar que cada ciudadano tiene una "millonésima" cuota del poder para hacer la Constitución, reformarla y, sobre todo, intentar una defensa contra los abusos de las autoridades constituidas a cargo de los poderes públicos y de los cada vez más emergentes poderes privados.

El empleo de esta afirmación capital para la discusión teórica y dogmática encierra dos dimensiones. Por un lado, debe ser asumida como definición o postulado. Por otro lado, eso no inhibe el tendido paralelo de una red para recoger su explicación racional y su dominio ulterior, con la decidida tendencia de que la "malla sea cada vez más fina".

\section{§ II. Estrategia argumentativa}

En las secciones III y IV se cumple la tarea, en paralelo, dentro de la comprensión de dos niveles del saber jurídico constitucional: el "teórico" y el "dogmático". Al comienzo de cada sección se realiza una presentación compendiada de premisas teóricas. Inmediatamente, se cumple con la descripción exclusiva de la normatividad de la CPC 1991, cuyos "principios" y "reglas" -pertinentes y bajo escrutinio- son, o bien directa-

\footnotetext{
6 Popper, Karl R.: La lógica de la investigación científica, Madrid, Tecnos, 1962, p. 58.

7 En este escrito no asumo la distinción entre "principios" y "reglas", ni en sentido fuerte ni en sentido débil. No significa que la distinción no posea fundamento; simplemente, es
} 
mente aplicables, o aplicables tras construir otras disposiciones jurídicas a partir de sus prescripciones.

En las argumentaciones teóricas -subsecciones III.A, IV.Ano se contempla, en particular, un orden positivo constitucional determinado; a continuación de cada una -en las secciones III.B y IV.B, respectivamente- realizo una tarea dogmática que se nutre de las teóricas y, de este modo, describo las cualidades elementales, según se refiere en la CPC de 1991, sobre "pueblo y ciudadanía", sobre "autoridad de la Constitución" y sobre su protocolo de "variación". En la sección IV.C, al tratarse de un "Interludio" íntimamente conectado con la sección IV (en especial, la reforma constitucional), desarrollo, al mismo tiempo, argumentaciones dogmáticas, teóricas y de doctrina de naturaleza jurisdiccional.

El método elegido se encuentra fundado en el hecho de que los seres humanos, en particular los ciudadanos, constituyen el primer motor del Estado constitucional ${ }^{8}$, porque ellos

preciso señalar que tiene un alcance y un contenido explicativo bastante más reducido del que se le asocia, dado que la mayor parte de los principios, tendencialmente, se comportan como las reglas, porque también son "Derecho sobre Derecho" (Derecho constitucional sobre Derecho inferior a la Constitución), portadores de sana normatividad y que se emplazan en la cima del orden jurídico del Estado. Quizá podría aducirse que los "principios" evocan a menudo supuestos de hecho o insinúan situaciones o relaciones fácticas más abiertos que las "reglas", pero de allí no puede ni debe inferirse ninguna consecuencia jurídica diferente, porque -repito- las consecuencias de unos (los principios) y otras (las reglas) son siempre prescriptivas, ordenan su realización, dado que se orientan a dentro del marco de la normatividad del Derecho. Además, tanto principios como reglas contienen directrices o patrones sobre la determinación de conductas de personas y servidores públicos, cuyo cumplimiento resulta jurídicamente ineludible. Por último, la función normativa de los principios y de las reglas, en general, resulta acatada sin distinciones respecto del campo de cada uno de ellos por los destinatarios de los enunciados constitucionales: personas y servidores públicos. Sigo, en general, la consistente tesis de FerRajou, Luigi: "Constitucionalismo principialista y constitucionalismo garantista", en Un debate sobre el constitucionalismo, Madrid, Marcial Pons, 2012, pp. 11-50.

8 Peter HÄBERLE ha observado que quizás la formulación "más distinguida" de los textos constitucionales relativos a la ciudadanía sea la del Preámbulo de la Constitución de Brandeburgo (1992): "We, the citizens of the Land of Brandenburg, have given ourselves this Constitution in free self-determination'. ¡Los ciudadanos se sitúan en lugar del pueblo como poder constituyente! ¡Una despedida de [Juan Jacobo] Rousseau!". V. HäBeRLE, Peter: 
son los artífices de los artefactos: "Estado" y su fundamento inseparable, la Constitución. Se entiende por "Estado constitucional" todo ente que congrega en su composición dos elementos constituyentes naturales (territorio y pueblo) y dos elementos constituyentes no naturales (poder y Constitución); su directriz básica es que todo el Derecho debe ser Derecho genuinamente autorizado por la norma positiva fundamental de su orden coactivo.

En la sección III trato uno de los elementos naturales, el pueblo integrado por ciudadanos. En sección siguiente (IV), la Constitución y su reforma. Y en la subsección IV.C, un fenómeno típicamente colombiano: la doctrina de la inconstitucionalidad del acto reformatorio de la Ley mayor por "sustitución”. Procedo de dicho modo porque, como se verá, el artefacto (Constitución) siempre es creado (o reformado) por su artífice (los representantes de los ciudadanos que integran el pueblo).

En la sección $\mathrm{V}$ formulo los comentarios de cierre.

\section{§ III. Pueblo y ciudadano. Premisas teóricas. Descripción de la Constitución Política de Colombia de 1991}

\section{III.A. Proposiciones dogmáticas}

1. El pueblo, como elemento natural del Estado, es un sujeto jurídico colectivo integrado por el conjunto de personas que quedan sometidas a un orden jurídico determinado e instituido. Cada uno de los integrantes del pueblo es un sujeto individual, natural e insustituible, llámese "nativo", "ciudadano" o "extranjero".

2. El pueblo de un Estado, por lo general, puede ser comprendido desde dos perspectivas, una genérica y otra más estricta. Así, "pueblo", en el primero de los sentidos, hace referencia a los nativos (nacidos en ese determinado lugar, empero,

“Ciudadanía a través de la educación como objetivo europeo", en Academia. Revista sobre enseñanza del Derecho, año 4, nº 7, 2006, p. 107. 
todavía, no son ciudadanos) y también a los ciudadanos, porque tienen un rasgo distintivo, la titularidad de derechos y deberes políticos. Además, deben incluirse los extranjeros que habitan en el territorio del Estado, quienes, por lo general, gozan de una gama de derechos civiles, sociales y de libertad, pero no disponen de derechos políticos como un ciudadano.

En un sentido más restringido, "pueblo" abarca solamente a los ciudadanos, personas que poseen soberanía sobre su propio itinerario vital, y por eso comparten la titularidad y el ejercicio de la autodeterminación política comunitaria ${ }^{9}$ con todos sus conciudadanos semejantes. En esta subsección me ocupo de esta última noción: el pueblo integrado por ciudadanos, personas individuales que comparten y concurren, básicamente, con otros conciudadanos, en las mismas situaciones y relaciones jurídicas, que se constituyen para todos con igual forma y contenido básico.

3. Uno de los méritos que pueden ser vislumbrados como eternos de la Declaración de los Derechos del Hombre y del Ciudadano de 1789 (DDHC) ${ }^{10}$ consiste en la distinción realizada

9 El Pacto Internacional de Derechos Civiles y Políticos (1966) de las Naciones Unidas define en su art. 1.1. “Todos los pueblos tienen el derecho de libre determinación. En virtud de este derecho establecen libremente su condición política y proveen asimismo a su desarrollo económico, social y cultural". Pareciera que la titularidad del derecho debería ser interpretada como asentada en el sujeto colectivo: "pueblo". Sin embargo, desde que el pueblo no puede existir sin la suma de las individualidades de cada una de las personas naturales que lo integran, porque es su constituyente elemental, no cabe desechar ni dejar de inferir, también, una titularidad individual del derecho de autodeterminación que coexiste con la apuntada naturaleza colectiva. Seré más decidido, todavía: un ente soberano, el Estado, no puede existir de la nada ni nacer por reproducción natural o generarse de manera mágica, ya que es un artificio, pura invención y consecuente fundación de los seres humanos. Su soberanía política sólo puede ser explicada a partir de la soberanía de los millones de individuos que deciden su creación, desarrollo y mantenimiento.

10 Desde el prólogo de la DDHC se orienta o establece una distinción entre "derechos del hombre" y "derechos del ciudadano". El texto que se reproduce, aunque contiene los dos términos ("hombre" y "ciudadano"), no tiene la contundencia explicativa que sí se puede apreciar dentro de la textura del articulado de la DDHC. Se lee, pues, en la introducción: "Los Representantes del pueblo francés, constituidos en Asamblea Nacional, considerando que la ignorancia, el olvido o el menosprecio de los derechos del hombre son las únicas causas 
entre "derechos de la personalidad" -que invisten a todo ser humano y del que son titulares en cuanto individuo o persona natural- y los "derechos de ciudadanía" -que sólo pueden titularizar determinadas personas en cuanto ciudadanos.

\section{Derechos del hombre:}

I. Los hombres nacen y permanecen libres e iguales en derechos. Las distinciones sociales sólo pueden fundarse en la utilidad común.

II. La finalidad de toda asociación política es la conservación de los derechos naturales e imprescriptibles del hombre. Esos derechos son la libertad, la propiedad, la seguridad y la resistencia a la opresión.

IV. La libertad consiste en poder hacer todo aquello que no cause perjuicio a los demás. El ejercicio de los derechos naturales de cada hombre, no tiene otros límites que los que garantizan a los demás miembros de la sociedad el disfrute de los mismos derechos. Estos límites sólo pueden ser determinados por la ley.

V. La ley sólo puede prohibir las acciones que son perjudiciales a la sociedad. Lo que no está prohibido por la ley no puede ser impedido. Nadie puede verse obligado a aquello que la ley no ordena.

VII. Ningún hombre puede ser acusado, arrestado y mantenido en confinamiento, excepto en los casos determinados por la ley, y de acuerdo con las formas por ésta

\footnotetext{
de las calamidades públicas y de la corrupción de los gobiernos, han resuelto exponer, en una declaración solemne, los derechos naturales, inalienables y sagrados del hombre, para que esta declaración, constantemente presente para todos los miembros del cuerpo social, les recuerde sin cesar sus derechos y sus deberes; para que los actos del poder legislativo y del poder ejecutivo, al poder cotejarse en todo momento con la finalidad de cualquier institución política, sean más respetados y para que las reclamaciones de los ciudadanos, fundadas desde ahora en principios simples e indiscutibles, redunden siempre en beneficio del mantenimiento de la Constitución y de la felicidad de todos. En consecuencia, la Asamblea Nacional reconoce y declara, en presencia del Ser Supremo y bajo sus auspicios, los siguientes derechos del Hombre y del Ciudadano..." (énfasis agregado). Asimismo, en la obra del constitucionalista argentino Sánchez Viamonte, Carlos: Los Derechos del hombre en la revolución francesa, México, D.F., UNAM, Dirección General de Publicaciones, 1956, pp. 97-299, se ilustran discursos y proyectos sobre la DDHC en la Asamblea Nacional francesa de 1789.
} 
prescritas. Todo aquél que promueva, solicite, ejecute o haga que sean ejecutadas órdenes arbitrarias, debe ser castigado, y todo ciudadano requerido o aprendido por virtud de la ley debe obedecer inmediatamente, y se hace culpable si ofrece resistencia.

VIII. La ley no debe imponer otras penas que aquéllas que son estricta y evidentemente necesarias; y nadie puede ser castigado sino en virtud de una ley promulgada con anterioridad a la ofensa y legalmente aplicada. IX. Todo hombre es considerado inocente hasta que ha sido declarado convicto. Si se estima que su arresto es indispensable, cualquier rigor mayor del indispensable para asegurar su persona ha de ser severamente reprimido por la ley.

$X$. Ningún hombre debe ser molestado por razón de sus opiniones, ni aún por sus ideas religiosas, siempre que al manifestarlas no se causen trastornos del orden público establecido por la ley.

XI. Puesto que la libre comunicación de los pensamientos y opiniones es uno de los más valiosos derechos del hombre, todo ciudadano puede hablar, escribir y publicar libremente, excepto cuando tenga que responder del abuso de esta libertad en los casos determinados por la ley. XVII. Siendo inviolable y sagrado el derecho de propiedad, nadie podrá ser privado de él, excepto cuando la necesidad pública, legalmente comprobada, lo exige de manera evidente, y a la condición de una indemnización previa y justa.

\section{Derechos del ciudadano:}

III. La fuente de toda soberanía reside esencialmente en la Nación; ningún individuo, ni ninguna corporación pueden ser revestidos de autoridad alguna que no emane directamente de ella.

VI. La ley es expresión de la voluntad de la comunidad. Todos los ciudadanos tienen derecho a colaborar en su formación, sea personalmente, sea por medio de sus representantes. Debe ser igual para todos, sea para 
proteger o para castigar. Siendo todos los ciudadanos iguales ante ella, todos son igualmente elegibles para todos los honores, colocaciones y empleos, conforme a sus distintas capacidades, sin ninguna otra distinción que la creada por sus virtudes y conocimientos.

XIII. Siendo necesaria, para sostener la fuerza pública y subvenir a los gastos de administración, una contribución común, ésta debe ser distribuida equitativamente entre los ciudadanos, de acuerdo con sus facultades.

XIV. Todo ciudadano tiene derecho, ya por sí mismo o por su representante, a constatar la necesidad de la contribución pública, a consentirla libremente, a comprobar su adjudicación y a determinar su cuantía, su modo de amillaramiento, su recaudación y su duración.

Disposiciones comunes a los derechos del hombre y del ciudadano:

XII. Siendo necesaria una fuerza pública para garantizar los derechos del hombre y del ciudadano, se constituirá esta fuerza en beneficio de la comunidad, y no para el provecho particular de las personas a las que ha sido confiada.

Como se podrá apreciar, en el ámbito de la DDHC la cabal distinción entre derechos de la personalidad y derechos de ciudadanía no se refiere a cualidades estructurales entre las dos categorías de sujetos, sino que subyace por la determinación efectuada en la formulación expresa de sus enunciados normativos. Dentro de la aludida comprensión, la diferencia entre "hombres" y "ciudadanos" resulta un elemento netamente contingente de la clase de sujetos a los que fue asignado el emplazamiento por el orden jurídico ${ }^{11}$.

4. El criterio seguido para distinguir derechos de la personalidad y derechos de la ciudadanía responde, con pureza, a la dimensión de la subjetividad jurídica; concretamente: los alcances en su titularidad. La ciudadanía es un eje que vincula a la persona

11 Ferrajol, Luigi: Principia iuris. Teoría del Derecho y de la democracia, t. 1: "Teoría del Derecho", Madrid, Trotta, 2011, p. 691. 
con su pertenencia a un Estado determinado. Desde tal comprensión, el derecho -y los deberes- de ciudadanía encierran un elemento de exclusividad y discriminación: sólo pueden ser ciudadanos las personas que determinado orden emplaza para un determinado Estado, a condición, desde luego, de su capacidad de obrar. Paralelamente, se excomulga a todas aquellas personas naturales que carecen de la posibilidad de ser emplazadas, en los términos prescritos para la relación de ciudadanía.

5. La distinción entre derechos del hombre y derechos del ciudadano depende con exclusividad del Derecho positivo, es decir, del hecho de que haya sido conferida la titularidad a todos los seres humanos en cuanto personas naturales (derechos del hombre) y a todas las personas naturales en cuanto ciudadanos.

6. La ciudadanía se puede caracterizar a partir de la "titularidad" o singularidad del emplazamiento de la persona en el estatus de ciudadano. Nótese que también se la puede escudriñar a partir de la "estructura" de esos derechos fundamentales contenidos en la ciudadanía, más precisamente, de su naturaleza deóntica. Así, dentro del género "derechos fundamentales" Luigi Ferrajoli distingue la siguiente tipología: los derechos civiles, los derechos políticos, los derechos de libertad y los derechos sociales. Los derechos civiles y los derechos políticos son "derechos-poderes" o "derechos de autonomía"; léase: los derechos civiles, en el ámbito privado y los derechos políticos, en la esfera pública. Ambos, los derechos civiles y los derechos políticos, se caracterizan porque su ejercicio consiste en decisiones: actos jurídicos que producen consecuencias relevantes por la acción de sus titulares. Además, los derechos civiles presuponen la capacidad de obrar del titular en la esfera civil; mientras que los derechos políticos suponen semejante cualidad en la esfera de los asuntos públicos. Por su parte, los derechos de libertad y los derechos sociales son "derechos-expectativa", dado que consisten, respectivamente, en expectativas negativas y positivas, ya que implican, por parte de los poderes públicos, prohibiciones de interferencia, en el caso de los derechos de libertad, y obligaciones de prestación, en el caso de los derechos 
sociales $^{12}$. En la inmensa mayoría de los órdenes jurídicos estatales, los derechos políticos, estrictamente, se asocian a la ciudadanía y se constituyen en su ADN.

7. Repárese, sin embargo, que si bien es cierto que la interesantísima tipología sobre los "derechos" formulada por el eminente profesor de la Università degli Studi Roma Tre es útil para indagar respecto de la estructura deóntica de los derechos, no puede perderse de vista que es inimaginable un ejercicio de la ciudadanía sin el pleno ejercicio de los derechos de libertad, en todos sus aspectos. Ni siquiera es suficiente con los derechos de libertad para un cabal ejercicio de la ciudadanía, porque la persona puede ser libre respecto del Estado, pero sometida al aparato productivo.

Por lo tanto, la libertad política no basta, porque si a la persona se la reduce, se la somete a los designios de "poderes salvajes"13 -verdaderas potencias sin territorio que intentan globalizar la producción económica y monopolizar la banca y las finanzas sin atisbo de cooperación-, su libertad social queda pulverizada. La libertad política del individuo, por ende, debe

12 Ferrauol, Luigi: Derechos y garantías. La ley del más débil, Madrid, Trotta, 1999, p. 105.

13 Los poderes de los más fuertes, en cuanto sin límites, arbitrarios y no sujetos a reglas de ninguna especie, recorren la filosofía y la literatura. La evocación a Trasímaco puede resultar inmediata: "Yo digo que lo justo no es otra cosa que lo que le conviene al más poderoso". V. Platón: República, Buenos Aires, Losada, 2007, p. 125 (338c). Jack London escribió en un cuento publicado en 1914: "Algún día [...] todos los necios habrán muerto, y entonces todos los que estén vivos caminarán hacia adelante. Suya será la fuerza de los fuertes y unirán su fuerza de modo que ni un solo hombre en el mundo luche contra otro" (La fuerza de los fuertes, Buenos Aires, Ediciones IPS, 2016, p. 51). Por su parte, la expresión "poderes salvajes" es utilizada por Ferrajoli en Poderes salvajes. La crisis de la democracia constitucional (Madrid, Trotta, 2011, pp. 45-46), quien refiere, a su vez, que la expresión alude claramente a Kant: "El acto por el que el pueblo mismo se constituye como Estado es el contrato originario, según el cual todos en el pueblo renuncian a su libertad exterior, para recobrarla en seguida como miembros de una comunidad, es decir, como miembros del pueblo considerado como Estado; y no puede decirse que el hombre en el Estado haya sacrificado a un fin una parte de su libertad exterior innata, sino que ha abandonado por completo la 'libertad salvaje y sin ley', para encontrar de nuevo su libertad en general, íntegra, en la dependencia legal, es decir, en un estado jurídico; porque esta dependencia brota de su propia voluntad legislativa" (KANT, Immanuel: La metafísica de las costumbres, Madrid, Tecnos, 2008, pp. 145-146-énfasis agregado-). Los poderes salvajes son facultades brutales de los más fuertes, quienes no respetan o tratan de eludir las reglas que se encuentran jurídicamente impuestas, 0 tratan de escribir las bases del Derecho sólo a favor de su codicia sin límites. 
relacionarse a la ordenación del Estado, y la libertad social, a la ordenación y distribución de bienes y servicios; una y otra esfera de la libertad instituyen el corazón de la pertenencia comunitaria de la persona natural. La opción entre derechos de libertad y derechos sociales resulta errada para capitalizar la noción de ciudadanía; la libertad política se desvanece, se agota por completo si, en paralelo, no se satisface un trato mínimo, racional e indisponible de los derechos sociales. ¿Por qué?

La razón es simple: quienes no tengan derechos sociales lucharán por ellos; así lo demuestra la historia de la civilización. La libertad sin pan será usada para conseguir el pan; si se negare el disfrute o acceso a este último, perderían el pan y la libertad. A su turno, quienes dispongan del pan sin libertad perderían el control de su reparto en poco tiempo, que dejaría de ser igualitario para todos, porque muchos o algunos lucharían por la libertad que, desde mucho antes y por su desgarradora ausencia o restricción irracional, los ha colocado en situación desigual ${ }^{14}$.

Pero hay más. Los derechos civiles (personalísimos, obligacionales y contractuales, reales y de la familia) integran la suculenta base de cualquier persona natural, motivo por el cual tampoco es dable describir la ciudadanía sin acoger, pulcramente, a esta especie de derechos. En definitiva, la conexión entre ciudadanía y derechos fundamentales ha sido detallada por el poeta: "Para todos pan [y] para todos rosas"15. Debo decir: una sociedad de individuos igualados en derechos de libertad, con acceso vigoroso a los derechos sociales y con los derechos civiles en conexión con los unos y con los otros.

8. En la desenvoltura cotidiana de la dogmática jurídica hay un lenguaje bastante coloquial, poseedor de notoria imprecisión semántica; se discurre, en el ágora, respecto de una "ciudadanía formal" y una "ciudadanía material"16. Aunque el Derecho (y

\footnotetext{
14 Zaffaroni, E. Raúl: “ ¿Estado gendarme o Estado fraterno?”, ob. cit.

15 Éluard, Paul: Obras escogidas, Buenos Aires, Platina, “El rostro de la paz" [1951], 1962, p. 80.

16 Respecto de la dogmática o doctrina de los autores, sirva de consuelo insuficiente el texto de Julio Cortázar: "Todo cuento es como se lo cuenta, la conciencia de que fondo y forma
} 
el saber dogmático que debe describirlo) instituyen, esencialmente, un lenguaje, un mundo de signos y significados, en la medida que su función normativa es socialmente compartida y reconocida como vinculante ${ }^{17}$, resulta cuanto menos inútil, por ausencia en la determinación de las propiedades semánticas, acudir a "formal" y "material", cuya polisemia viene siendo discutida desde hace cientos de años por los estudios de la filosofía y la física, respectivamente. Quizá, intuyo, se desea aludir a diferentes modelos de justificación del ente estatal meramente instrumentales, en un caso (ciudadanía formal) y profundamente sustanciales (ciudadanía material), en el otro.

Con el anuncio de una "ciudadanía formal”, quizá se configure una alusión al ejercicio de algunos de los derechos civiles, a los derechos de libertad y a los derechos políticos. La noción de ciudadanía formal, si acaso cupiere, perseguiría fundar o justificar quiénes son los sujetos o personas que actúan en el ámbito de los negocios privados de la comunidad y en los negocios públicos del Estado; también, el modo en que se instrumentan la decisiones, tanto en una esfera como en la otra.

A su turno, la noción de "ciudadanía material" señalaría una posible justificación de las decisiones en la comunidad; en este caso, con una vinculación más estrecha con la satisfacción de los derechos sociales. Concebida la ciudadanía como un estatus que se otorga a los que son miembros de pleno Derecho de una comunidad, razón por la cual todos los que poseen ese "estatus"18 son iguales en lo que se refiere a los derechos y deberes, pareciera más indicado referirse a un "sentido parcial" de ciudadanía y a un "sentido pleno" de ciudadanía, que, sin

\footnotetext{
no son dos cosas, es lo que hace al buen narrador oral, que no se diferencia así del buen escritor aunque los prejuicios y los editores estén a favor de este último" (énfasis agregado). "De la seriedad en los velorios", en la Vuelta al día en ochenta mundos, Buenos Aires, Siglo Veintiuno, 2014, p. 51.

17 Ferrajolı, Luigi: Principia iuris. Teoría del Derecho y de la democracia, t. 1, ob. cit., p. 801.

18 MarShall, Thomas Humphrey: “Ciudadanía y clase social”, Revista Española de Investigaciones sociológicas, $\mathrm{n}^{0}$ 79, Madrid, 1997, p. 312.
} 
dudas, se corresponderían con los predicados atribuidos a la ciudadanía formal y a la ciudadanía material, respectivamente, pero con mayor vigor. Eso sí, habrá un "círculo diabólico" en el que se debate la "ciudadanía parcial", en todo momento. Porque la insatisfacción de los derechos sociales básicos hará pensar que todo ser humano que titularice una ciudadanía parcial, pero carezca de dicho acceso, siempre encontrará debilitada su inserción y participación política hasta tanto no acceda, con una base mínima y racional, a la educación, al trabajo y a la salud.

9. En América del Sud existen varias ciudadanías estatales: una ciudadanía argentina, una boliviana, una colombiana, una brasileña, una ecuatoriana, una paraguaya, una peruana, una uruguaya, una venezolana y una chilena. Cada uno de esos estatus, en verdad, instituyen una situación privilegiada en derechos y deberes, actuales e ineludibles, en vinculación con cada uno de los órdenes jurídicos estatales respectivos. Considero que se hace menester pensar en una ciudadanía sudamericana, fundada en un constitucionalismo de y para América del Sud, un nuevo orden supraestatal con garantías suficientes que, sin rechazar la noción clásica de ciudadanía y su vínculo permanente, pueda superar la dicotomía "derechos del hombre-derechos del ciudadano" y ampliar, con un nuevo marco de referencia, el ámbito de la gobernanza para beneficio de gobernados y gobernantes. La utopía merecería ser desestimada en caso de no existir un sujeto sudamericano, un patrimonio común, un ideario global y una comprensión del mundo compartida. En cambio, cobraría actualidad si se llegare a la conclusión de que en América del Sud hay un ser humano que se va abriendo paso en la historia en permanente resistencia a cualquier régimen de dominación, que le niega o retacea su dignidad de persona, en un territorio en que muchos millones de seres humanos interactúan y sincretizan sus cosmovisiones, que son expresión de todas las culturas sometidas y marginadas por el colonialismo en todo el mundo. ${ }^{19}$

19 Zaffaroni, E. Raúl: El Derecho latinoamericano en la fase superior del colonialismo, Buenos Aires, Ediciones Madres de Plaza de Mayo, 2015, p. 6. 
Frente a esta cuestión, la diferencia en la titularidad de los derechos fundamentales que singularizan los derechos -y deberes- inherentes a la ciudadanía, si se la compara con los "derechos del hombre", se puede especular con ingenuo entusiasmo o con franco pesimismo -prefiero este último. Con la franqueza que proviene de un pesimismo inteligente, la pregunta no debería ser si los hombres en América del Sud accederán, finalmente, a una nivelación de equidad o igualdad que dé lugar a una cosmopolita ciudadanía sudamericana, plena y activa (que con toda seguridad no lo serán jamás ni sucederá nunca). Según conjeturo, el desarrollo constante de los órdenes estatales abrirá paso y reclamará, más temprano que tarde, que todo hombre sudamericano disponga de una ciudadanía sudamericana peculiar, fundada, en especial, en una subjetividad jurídica, comprometida, y que descanse, por el mismísimo hecho de su "pertenencia", en los valores de la libertad, la igualdad y, sobre todo, la solidaridad o fraternidad con todas las personas naturales que habitan el subcontinente. Los modelos que podría asumir una ciudadanía sudamericana dependen de la inmensa gama de modalidades y expectativas que pueden reunir las relaciones y situaciones jurídicas. Sin embargo, los derechos de residencia, circulación y libre tránsito (entrada y salida del Estado) deberían ser considerados en la misma primera fase sobre la normatividad de una futurible subjetividad ciudadana sudamericana. ${ }^{20}$

20 En el siglo XXI se exhibe un notable esfuerzo para una relación más solidaria entre los Estados. Así, cabe mencionar que el 23 de mayo de 2008 se suscribió el Tratado constitutivo de la Unión de Naciones Suramericanas. Allí se ha consignado que "La República Argentina, la República de Bolivia, la República Federativa del Brasil, la República de Colombia, la República de Chile, la República del Ecuador, la República Cooperativa de Guyana, la República del Paraguay, la República del Perú, la República de Surinam, la República Oriental del Uruguay y la República Bolivariana de Venezuela" han acordado “... constituir la Unión de Naciones Suramericanas (Unasur) como una organización dotada de personalidad jurídica internacional" (art. 1). Se ilustra, seguidamente, como objetivo de la Unasur "... construir, de manera participativa y consensuada, un espacio de integración y unión en lo cultural, social, económico y político entre sus pueblos, otorgando prioridad al diálogo político, las políticas sociales, la educación, la energía, la infraestructura, el financiamiento y el medio ambiente, entre otros, con miras a eliminar la desigualdad socioeconómica, lograr la inclusión social y 
10. La participación de ese hombre, al que se emplaza como ciudadano, autoriza a pensar la introducción del Derecho en el mundo. El Derecho constitucional, rama fundamental del orden jurídico, observa semejante proceso creativo que su género próximo, el Derecho estatal. De ello se deriva que los individuos, únicos constituyentes del Derecho constitucional, sólo han de ser las personas naturales, a quienes corresponde en exclusiva el poder de instauración primigenia, que está en el origen de todo el Derecho positivo, en principio, la constitución del Estado, porque la fundación de todo el Derecho se realiza por seres humanos. Quizá, en el futuro, el Derecho constituyente del Estado sea instituido, tecnológica y científicamente, con una participación distinta del ser humano. Hoy, en pleno 2018, todavía no se puede ni especular sobre los trazos de la futurible producción del Derecho constitucional, si, acaso, en cientos de años ha de mantener su existencia o determinar el itinerario de su evolución. En cambio, me encuentro en perfectas condiciones para afirmar que en el nacimiento y en el desarrollo del constitucionalismo, desde el siglo xviI hasta el presente, los únicos creadores han sido las personas humanas, seres constituyentes que, al unir sus individualidades como sujetos soberanos, dan lugar al Estado constitucional.

Los seres humanos son los artífices del Derecho constitucional; no hay otro creador o autor. El Derecho constituyente del Estado, el Derecho constitucional que emana de los principios y reglas constitucionales, es un artificio creado por el ser humano. Por ende, los seres humanos de carne y hueso, sola y exclusivamente, se convierten en un "presupuesto" del Derecho constitucional, en la inteligencia de que son sus excluyentes fundadores. Las instituciones de un Estado, los órganos o ramas del poder, "presuponen" el Derecho constitucional porque son fundadas por el imperativo de sus enunciados normativos ${ }^{21}$.

la participación ciudadana, fortalecer la democracia y reducir las asimetrías en el marco del fortalecimiento de la soberanía e independencia de los estados" (art. 2). El Tratado entró en vigor el 11/3/2011. Un buen comienzo.

21 Ferrajolı, Luigi: Principia iuris. Teoría del Derecho y de la democracia, t. 1, ob. cit., p. 346. 
El poder constituyente, integrado por los representantes de los ciudadanos que forman el pueblo del Estado, elabora y establece la norma constitucional, cuyo paso final, en ocasiones, también se remite a la aprobación del cuerpo electoral. En el momento constituyente de la creación jurídica originaria o en el momento constituyente de su variación, también se establecen las atribuciones para generar normas de rango inferior a la Constitución.

\section{III.B. Justificación del asunto}

Primero. Difícilmente la organización política del mundo podría ser como todas las personas desean. La existencia en la comunidad no puede ser distinta de la vida individual de cada persona. Todos los seres humanos tienen deseos, pero tal como ha sido impuesta su existencia nunca pueden cumplirse, ni siquiera en su gran mayoría. El mismo reporte que emerge de la vida individual -me refiero a la inefectividad de gran parte de los deseos- se ha de trasladar a la vida comunitaria del Estado, porque dicho ente es fruto del obrar humano. Por lo pronto, en particular, el tipo "Estado constitucional" 22 es un instrumento para intentar subordinar la política a la actuación constante y robusta de los principios vinculantes que impone el Derecho que emana de la Ley fundamental. Más allá del grado de la mayúscula o de la minúscula eficacia de las reglas impuestas por el Derecho constitucional, éste se trata de la única invención conocida para armonizar las existencias de los individuos al fijar "determinados contenidos" y "determinados procedimientos esenciales" en el marco canonizado por una sociedad abierta de individuos libres.

Segundo. El pueblo del Estado, entendido en sentido restringido como el conjunto de los integrantes con derechos y deberes políticos -sus ciudadanos-, no puede ser captado como un todo colectivo homogéneo que tiene, por tanto, un interés

22 HäBerle, Peter: El Estado constitucional, $2^{\text {a }}$ ed., México D.F., IIJ, 2016, p. 3. 
colectivo unitario y que se expresaría en una voluntad colectiva unitaria. Es cierto que toda comunidad de personas naturales requiere de un instrumento que determine la ordenación de las existencias en la comunidad. No obstante, de ello no puede derivarse la inexistencia de intereses diversos y hasta antagónicos. Los ciudadanos que integran el pueblo poseen diferentes ideologías. Así, por ejemplo, de un lado siempre habrá ideas conservadoras de las condiciones originarias que enfatizan la protección de los derechos civiles (en particular, la defensa más o menos irrestricta del derecho de propiedad privada ${ }^{23}$ ) y del

23 El derecho de propiedad es un derecho singular. Pareciera que todas las personas pueden ser titulares, pero el mercado, gobernado por la codicia del capitalismo, muestra desde el mismo nacimiento del constitucionalismo, en el siglo xVIII, que la capacidad material para ser propietario queda determinada por la clase social. Para quienes no disponen de una propiedad, el derecho constituye una expectativa, muchas veces una ilusión para poseer jurídicamente -añado: siempre en caso de que el individuo pueda acceder a su titularidad. En cambio, si la propiedad ya fue adquirida, como sucede, por ejemplo, en la Argentina con el art. 14 de su Constitución federal argentina (CFA), al decidir en 1853 que todos los habitantes gozan del derecho de "usar y disponer de su propiedad", sin dudas dispondrán de todo tipo de instrumentos para su protección. Nótese, además, que "usar" y "disponer" son verbos constitucionales que generan una tipicidad únicamente dirigida para la clase de individuos que tienen una o varias propiedades, razón por la cual pareciera que la Ley fundamental de la Argentina constitucionalizó una relación anterior y predispuesta en la comunidad. En otras palabras, la CFA dio forma jurídica a una situación de hecho anterior a su sanción, esto es, el hecho de que un puñado de terratenientes disponían, fácticamente, de la capacidad material de ser propietarios. El derecho de propiedad, especie paradigmática de los derechos civiles patrimoniales, impide, por definición, su propia universalidad, porque para que un sujeto sea titular de la relación de titularidad propietaria habrá que excluir, siempre, a todo otro individuo. Por tanto, al no ser disponible por todos y en igual medida, del derecho de propiedad no podrá argumentarse que todos los seres humanos son "iguales en derechos" (Déclaration des droits de I'homme et du citoyen de 1789: Art. 1er: "Les hommes naissent et demeurent libres et 'égaux en droits'); como sí puede afirmarse, en principio, sobre los derechos de libertad, los derechos sociales o los derechos políticos. La exclusividad del derecho de propiedad, que singularizará siempre su reconocimiento y titularidad jurídica, ha de provocar que no pueda ser disfrutado por otros. La ausencia de esta cualidad -la universalidad-impediría considerar al derecho de propiedad como un derecho fundamental que pueda ser disfrutado igualmente por todos los seres humanos sin exclusión. La inclusión, sin barreras ni sospechas ni privilegios, debería constituir la igualdad universal e inmarcesible de los derechos fundamentales: de libertad, políticos, civiles no patrimoniales y sociales. En el art. 58 de la CPC 1991 "se garantizan la propiedad privada y los demás derechos adquiridos". La posición de garante debe ser atribuida al Estado. También, al igual que en la CFA, la disposición colombiana alumbra el presente y el futuro de los propietarios. 
ejercicio de los derechos políticos, sin discutir las bases de la igualdad social; y, por otro, existirán ideas progresistas que, sin mancillar los derechos políticos, alientan un franco desarrollo de los derechos sociales con carga al Estado y una equitativa distribución de la riqueza de bienes yacentes y por crearse. Estas ideas muchas veces se contradicen porque la contraposición de intereses resulta inevitable, fiel muestra de las clases sociales. En este sentido, Hans Kelsen lo ha señalado con lucidez por el hecho de que no sólo es cuestionable la idea del "pueblo unido", sino que no existe la "voluntad general" del pueblo" ${ }^{4}$.

La cruda inexistencia de una voluntad general, omnímoda y homogénea, vinculada con la ausencia de la unidad cierta de un pueblo, no implica que no pueda existir un proceso augusto, digno de un consenso extendido y venerado, en el que mayoría y la minoría de los ciudadanos se permiten establecer quiénes formularán, y sobre todo cómo se adoptarán, las decisiones que han de regir la vida pública de la comunidad. Las reglas de juego de ese proceso se formalizan en la Constitución y desde allí deberían constituirse un escenario plural, en el que todos los ciudadanos tengan garantizados los siguientes derechos: de reunirse; de residir; de peticionar; de protestar; de circular libremente; de entrar y salir del territorio del Estado; de expresar sin ningún tipo de censura o coacción sus opiniones por cualquier medio, derecho cuyo contenido sólo debe quedar librado a la responsabilidad ulterior del hacedor de los pensamientos; de formar, integrar y deshacer grupos, asociaciones y partidos políticos y, sin que implique agotar la lista de derechos, de gozar de

Sin embargo, hay una diferencia radical entre los textos argentino y colombiano; en efecto,
en el segundo párrafo del art. 58 de la CPC 1991 se prescribe que "La propiedad es una
función social que implica obligaciones"; la CFA guarda silencio -total y desgarrador- sobre
la cuestión. Pero hay más. En el art. 64 de la CPC 1991 se ordena que "Es deber del Estado
el acceso progresivo a la propiedad de la tierra de los trabajadores agrarios, en forma indivi-
dual o progresiva"; se trata, en pureza, de una regla sobre la igualdad material; en este caso,
lamentablemente, la CFA nada dice y con ello justifica el latifundio, la precarización del peón
rural y las rentas exorbitantes para los dueños de la tierra.
24 KELSEN, Hans: ¿Quién debe ser el defensor de la Constitución?, Madrid, Tecnos, 1995, p. 63. 
la posibilidad de elegir y de ser elegidos en comicios auténticos $\mathrm{y}$ transparentes en que los se pueda ejercer el sufragio universal, secreto, igual y en lo posible obligatorio.

Así, con el modelo que antecede, la Constitución queda delineada como un instrumento de naturaleza procesal $^{25}$ y marca un dominio en el que se prohíbe la descalificación, pulverización o cualquier forma de daño o distorsión de "quiénes" y "cómo" han de concretar la expresión ciudadana y el consecuente proceso de gobierno. Con claridad, la Constitución fija las pautas para decidir la gobernanza, que en toda república siempre se ha de caracterizar, mínimamente, por la división de las funciones gubernativas, la idoneidad del servidor público, su responsabilidad, la más acabada publicidad de los actos de gobierno y la periodicidad de los representantes del pueblo; así, pues, la Constitución, como regla previsible y determinante, autoriza la alternancia en el poder del Estado, pero jamás la aniquilación del propio sistema procesal que instituye,

Atribuir "la dirección suprema" de la ordenación estatal a los ciudadanos que integran el pueblo significa que no hay estamento por encima de ellos para realizarlo. La ciudadanía, definida por asignación de los derechos y deberes políticos, inviste a cada ciudadano para ejecutar un orden jurídico configurador de la realidad de una comunidad. No desconozco el hecho indisputable de que, por ejemplo, la República de Colombia posee un padrón electoral de más de 36.000.000 de ciudadanos ${ }^{26}$; allí, como en cualquier república sudamericana, no cabría o no correspondería esperar que el poder

\footnotetext{
25 En semejante sentido se expresa Juan Luis Requejo Pagés: “La normatividad de la Constitución y su caracterización como una norma procesal son las dos condiciones necesarias para la ordenación jurídica de una sociedad democrática; para la organización racional de la fuerza en una comunidad de individuos libres que puede resumirse en aquélla en la que el Estado no ejerce más poder que el que pueda admitir un individuo como agente racional y autónomo" (énfasis agregado). V. Requeso Pagés, Juan Luis: El sueño constitucional, Oviedo, KRK, 2016, p. 104.

${ }^{26}$ V. Registraduría Nacional del Estado Civil: https://www.registraduria.gov.co/-CensoElectoral,3661-.html, consultado por última vez el 24/5/2018.
} 
constituyente originario fuese ejercido en forma directa por semejante número de personas naturales. Dentro de la especie "de los ciudadanos", se deberán elegir "a los ciudadanos", esto es, a los "servidores públicos" -un verdadero acierto lingüístico de la CPC 1991-27, que cumplirán por representación con el acto de instauración de la Constitución.

Ello no devalúa el argumento principal respecto de la naturaleza de la dirección del proceso de configuración, el que únicamente puede descansar en el elemento atomístico por naturaleza, el ciudadano. En el mundo físico, acaso por una definición muy anticuada, el átomo fue concebido como el constituyente más pequeño de la materia; en el mundo del Estado y su configuración constitucional, el constituyente primero e indivisible es el ciudadano, quien es portador de una alícuota millonésima de poder inescindible para hacer la Constitución. En el mundo físico, la energía es un concepto clave; en el mundo del Derecho constitucional, el poder político global que se acuna en la sumatoria de las voluntades de todos y cada uno de los ciudadanos que integran el pueblo es el que dispone el momento de alumbramiento constituyente.

El caso de la variación constitucional colombiana (potestad atribuida al Congreso, conforme art. 374 de la CPC 1991) también se encuentra atado a la razón ciudadana. Esto es así, ya sea porque los representantes deben exhibir sus proyectos en las campañas electorales para no defraudar la confianza ciudadana; o ya sea porque se convoca a la ciudadanía que integra el pueblo a referendo; o porque los ciudadanos deben elegir representantes para una Asamblea constituyente, tal como explico -más adelante- en la subsección III.B. Quinto.

Tercero. En 1762 Juan Jacobo Rousseau lo expuso con genio: "Si hubiese un pueblo de dioses, se gobernaría democráticamente.

27 La CPC 1991 se refiere a los "servidores públicos" en repetidas ocasiones. Dogmáticamente, con buen método, el constituyente lo emplazó al comienzo: Título I, “De los principios fundamentales"; allí se prescribe, por ejemplo, en el art. 6: "Los particulares sólo son responsables ante las autoridades por infringir la Constitución y las leyes. Los servidores públicos lo son por la misma causa y por omisión o extralimitación en el ejercicio de sus funciones". 
Pero un gobierno tan perfecto no es propio de hombres"28. Varios siglos después, aún no existe un gobierno ideal. El único modo de concretar la autodeterminación comunitaria es por apelación a la representación política: las decisiones colectivas que afectan a toda la comunidad son adoptadas por personas elegidas, específicamente para tales fines, pero no directamente por aquellos individuos que formarán parte de los efectos de la deliberación y los efectos de lo decidido, en este último caso, muchas veces, bajo la forma de padecimiento.

Los representantes de los ciudadanos del pueblo no se encuentran ligados por un mandato imperativo, porque tienen el poder de actuar con determinada libertad en nombre y por cuenta de los representados, ya que al disponer de la confianza de éstos -mediada por el sufragio- pueden interpretar con propia deliberación y discreción los intereses de los ciudadanos. La representación, por lo tanto, es un instrumento indispensable, porque resulta inviable que todos los ciudadanos que integran el pueblo deban ser convocados, constantemente, para discutir, por ejemplo, las leyes necesarias para la gobernanza del Estado. La vida ordinaria transita por vía la representación; sin embargo, hay circunstancias extraordinarias en las que se deja paso a mecanismos directos para la formación de la decisión colectiva ciudadana ( $v$. gr. el referendo, la consulta, el cabildo abierto, la iniciativa legislativa, la revocatoria del mandato o el plebiscito -cfr. art. 103, CPC 1991-).

Cuarto. Todos, nacionales, ciudadanos y extranjeros, deben acatar la Constitución colombiana, las leyes y obedecer a las autoridades (art. 4, CPC, 1991). En el artículo 100, tercer párrafo, se instituye que "Los derechos políticos se reservan a los nacionales, pero la ley podrá conceder a los extranjeros residentes en Colombia el derecho al voto en las elecciones y consultas populares de carácter municipal o distrital". Mi intuición es que donde dice "nacionales" debería decir "ciudadanos", porque para su desarrollo la ciudadanía siempre implica una capacidad de obrar distinguida y bien determinada.

28 Rousseau, Jean-Jacques: El contrato social, Barcelona, Altaya, 1993, p. 67. 
La CPC de 1991, en el artículo 98, en su parágrafo, dispone que "Mientras la ley no decida otra edad, la ciudadanía se ejercerá a partir de los dieciocho años". En el artículo siguiente añade que "La calidad de ciudadano en ejercicio es condición previa e indispensable para ejercer el derecho de sufragio, para ser elegido y para desempeñar cargos públicos que lleven anexa autoridad o jurisdicción".

En Colombia, al igual que en casi todos los países de América del Sud, se emplaza la ciudadanía a partir de la determinación propia del poder constituyente. La positividad de la CPC 1991 determina la titularidad de las personas que han de ser ciudadanos. Por su parte, los extranjeros disfrutarán de los mismos derechos civiles que se conceden a los colombianos, aunque “... la ley podrá, por razones de orden público, subordinar a condiciones especiales o negar el ejercicio de determinados derechos civiles a los extranjeros”. También, “... los extranjeros gozarán, en el territorio de la República, de las garantías concedidas a los nacionales, salvo las limitaciones que establezcan la Constitución o la ley" (art. 100, CPC 1991).

Quinto. Más arriba he indicado la naturaleza política y las cualidades jurídicas de la participación del ciudadano. Concretamente, aludo a sus "derechos" y sus "deberes políticos". En el artículo 40 de la CPC 1991 se formula una enumeración de derechos políticos:

Todo ciudadano tiene derecho a participar en la conformación, ejercicio y control del poder político. Para hacer efectivo este derecho puede: 1. Elegir y ser elegido. 2. Tomar parte en elecciones, plebiscitos, referendos, consultas populares y otras formas de participación democrática. 3. Constituir partidos, movimientos y agrupaciones políticas sin limitación alguna; formar parte de ellos libremente y difundir sus ideas y programas. 4. Revocar el mandato de los elegidos en los casos y en la forma que establecen la Constitución y la ley. 5. Tener iniciativa en las corporaciones públicas. 6. Interponer acciones públicas en defensa de la Constitución y de la ley. 7. Acceder al desempeño de funciones y 
cargos públicos, salvo los colombianos, por nacimiento o por adopción, que tengan doble nacionalidad. La ley reglamentará esta excepción y determinará los casos a los cuales ha de aplicarse. Las autoridades garantizarán la adecuada y efectiva participación de la mujer en los niveles decisorios de la Administración Pública.

El sufragio es una pieza clave y determinante para configurar la elección de los representantes que han de deliberar y decidir el orden jurídico que se instituye y sus variaciones; ocasionalmente, para que el cuerpo electoral elija de manera directa. Al reglar el sufragio, los órdenes jurídicos asumen modelos obligatorios o facultativos. Así, en la Constitución federal de la Argentina (CFA) se dispone, por ejemplo, en su artículo 37 que el "sufragio es universal, igual, secreto y obligatorio". Dentro de la trama ordenada por el orden constitucional colombiano de 1991, debe inferirse la naturaleza facultativa, estrictamente voluntaria, del acto de sufragar (cfr. art. 40, CPC 1991). En el ámbito abstracto propio de una teoría constitucional determinada, la obligatoriedad del sufragio no debería afectar los derechos de libertad. Su naturaleza facultativa tampoco podría perjudicar, decisivamente, la elaboración de las razones del edificio estatal.

La construcción de una comunidad debería ser una apuesta colectiva, porque la participación mayoritaria de los ciudadanos apoyaría la posibilidad -no la determinaría concluyentemente de ningún modo- de que al gobierno escogido, electo, encargado de la ordenación política de la comunidad, se lo llame, en tal caso, "democrático" 29 . En el abanico de la libertad política, por supuesto enderezada a la ilusión democrática, se deben reconocer estas "instancias optativas mínimas": $a$ ) votar afirmativamente en apoyo del partido político "A"; $b$ ) votar afirmativamente en apoyo del partido político "B"; c) votar en blanco; $d$ ) emitir un voto nulo, o $e$ ) no votar.

29 RusselL, Bertrand: El poder en los pueblos y en los hombres, Buenos Aires, Losada, 1960, p. 141. 
Quizá, también, podría argüirse que la perspectiva liberal más ancha y decidida debería incluir -siempre- el ejercicio de la soberanía ciudadana, esto es, incluso, el "derecho" de no votar por ningún partido político. Por eso, con cierto fervor, al ser sugeridos de este modo los derechos de libertad política y analizados en correspondencia al sufragio, deberían incluir, al menos, las cinco opciones ilustradas. Esto es así porque la opción de "no votar" ha sido entendida en términos de una abstención, esto es, el hecho concreto de "no participar", que sería, si cotizare el verdadero contrasentido, un modelo o forma de participación. A su turno, tampoco puede adjudicarse que el voto obligatorio instituya y legitime, rotundamente, la construcción, más o menos ideal, de un orden comunitario.

Aunque no sostengo que el voto facultativo fuese antidemocrático, me inclino por la obligatoriedad del sufragio. Asumo que si la obligatoriedad de sufragar, además, se encontrara constitucionalmente dispuesta, el hecho de normar constituiría, en sí mismo, una determinación correcta. Advierto que la obligatoriedad del sufragio, instaurada en la Constitución, instituye un relevante deber para participar en la configuración del orden. Juzgo que no se afecta la atribución soberana de la libertad, al disponer la obligatoriedad de sufragar ${ }^{30}$. Así, el acto

30 La Convención Americana sobre Derechos Humanos (CADH) no decide la obligatoriedad del sufragio, aunque sí dispone, abiertamente, la más amplia libertad de elegir. Añado, por mi parte, que hubiese resultado impropia tal definición -la obligatoriedad del sufragio- en un instrumento sobre protección, preservación y promoción de los Derechos humanos, porque el acuerdo, en este caso de naturaleza internacional, debe cobijar diferentes comprensiones, entre las que se encuentra, desde luego, la abstención, no votar o genéricamente "no participar de los asuntos comunitarios" (v. art. 23 de la CADH: "Derechos Políticos 1. Todos los ciudadanos deben gozar de los siguientes derechos y oportunidades: a) de participar en la dirección de los asuntos públicos, directamente o por medio de representantes libremente elegidos; b) de votar y ser elegidos en elecciones periódicas auténticas, realizadas por sufragio universal e igual y por voto secreto que garantice la libre expresión de la voluntad de los electores, c) de tener acceso, en condiciones generales de igualdad, a las funciones públicas de su país. 2. La ley puede reglamentar el ejercicio de los derechos y oportunidades a que se refiere el inciso anterior, exclusivamente por razones de edad, nacionalidad, residencia, idioma, instrucción, capacidad civil o mental, o condena, por juez competente, en proceso penal"). En el caso "Castañeda Gutman vs. Estados Unidos Mexicanos", los jueces 
jurídico político de sufragar merece ser leído como un derecho y también como un deber, porque el hecho de coexistir de cada individuo en la comunidad implica la obligación a participar en las decisiones que me han de involucrar como ciudadano.

Además, en democracias como la colombiana, en la que el sufragio es facultativo, aunque la CPC 1991 dispone "un ciudadano, un voto", en la práctica, dada la gran abstención electoral persistente y recurrente, la fórmula electoral sería "dos ciudadanos, un voto" 31 , ya que, en el mejor de los casos, uno de cada dos ciudadanos colombianos tendrá el estímulo suficiente para ir a votar en los comicios, ya sea para elegir presidente, congresistas o cualquier otro cargo dependiente de escogimiento ciudadano. Sin embargo, admito que un "Estado constitucional" 32 puede fun-

de la Corte Interamericana de Derechos Humanos (CIDH) entendieron por unanimidad que la $\mathrm{CADH}$, al igual que otros instrumentos internacionales de derechos humanos, no establece la obligación de implementar un sistema electoral determinado [V. Párrafo 197]. También sostuvieron que "El derecho y la oportunidad de votar y de ser elegido consagrados por el artículo 23.1.b de la Convención Americana se ejerce regularmente en elecciones periódicas, auténticas, realizadas por sufragio universal e igual y por voto secreto que garantice la libre expresión de la voluntad de los electores. Más allá de estas características del proceso electoral (elecciones periódicas y auténticas) y de los principios del sufragio (universal, igual, secreto, que refleje la libre expresión de la voluntad popular), la Convención Americana no establece una modalidad específica o un sistema electoral particular mediante el cual los derechos a votar y ser elegido deben ser ejercidos. La Convención se limita a establecer determinados estándares dentro de los cuales los Estados legítimamente pueden y deben regular los derechos políticos, siempre y cuando dicha reglamentación cumpla con los requisitos de legalidad, esté dirigida a cumplir con una finalidad legítima, sea necesaria y proporcional; esto es, sea razonable de acuerdo a los principios de la democracia representativa". [Párrafo 149]. Sentencia pronunciada el 6/8/2008, "Excepciones preliminares, fondo, reparaciones y costas". Por su parte, el maestro Germán J. Bidart Campos, que mantenía su preferencia personal por el "sufragio voluntario", opinó que "no sentía herido ningún principio que se haga fundamental" en su valoración sobre el tema, por el hecho efectivo de que la reforma constitucional de 1994, en la Argentina (art. 37, CFA), constitucionalizó el deber del ciudadano de sufragar. V. Bidart CAmpos, Germán J.: Manual de la Constitución reformada, t. II, Buenos Aires, Ediar, 1998, pp. 253-254.

31 Bunge, Mario: Filosofía política. Solidaridad, cooperación y democracia integral, Barcelona, Gedisa, 2009, p. 475.

32 Se exponen dos modelos constitucionales de votación ciudadana, actualmente vigentes, en América del Sud. La pregunta que debería formularse es si la obligatoriedad del sufragio define la cualidad del Estado constitucional. Al respecto, cabe analizar la semántica 
cionar correctamente con la naturaleza voluntaria del sufragio. La distinción entre una y otra naturaleza consiste en aumentar o disminuir el compromiso político del ciudadano para con el desarrollo y la manutención del orden jurídico. Asimismo, la CPC 1991 adjudica a sus ciudadanos diferentes derechos políticos, que convierten al instrumento en un paradigma sobre la materia "reforma constitucional", en América del Sud ${ }^{33}$.

La Constitución colombiana, además, es portadora de un interesante listado de deberes ciudadanos. Así, solamente a título de ejemplo, se mencionan los siguientes enunciados normativos: si "el derecho a la vida es inviolable" (art. 11), resulta del deber correlativo para todos los seres humanos de no infringirlo; el deber de acatar la Constitución y las leyes, respetar y obedecer a las autoridades (art. 4); el deber de protección de las riquezas culturales y naturales del Estado (art. 8); el trabajo es una obligación social (art. 25); el deber de contribuir a la paz es de obligatorio cumplimiento (art. 21); el deber de procurar el cuidado integral de su salud y la de los integrantes de la comunidad (art. 49); la propiedad privada es una función social que implica obligaciones (art. 58); el deber de buena fe al que deben ceñirse las actuaciones entre particulares y el Estado (art. 83); la obligación de todos a tomar las armas cuando las necesidades públicas lo exijan para defender la independencia nacional y las instituciones públicas (art. 216).

Además, en el artículo 95 se detalla un catálogo de "deberes y obligaciones":

\footnotetext{
constituyente. Uno. En el art. 14 de la Constituição da República Federativa do Brasil de 1988 se determina que "A soberania popular será exercida pelo sufrágio universal e pelo voto direto e secreto, com valor igual para todos, e, nos termos da lei, mediante: I - plebiscito; II - referendo; III - iniciativa popular. § $1^{\circ} 0$ alistamento eleitoral e 0 voto são: I - obrigatórios para os maiores de dezoito anos; II - facultativos para: a) os analfabetos; b) os maiores de setenta anos; c) os maiores de dezesseis e menores de dezoito anos. § $2^{\circ}$ Não podem alistar-se como eleitores os estrangeiros e, durante o período do serviço militar obrigatório, os conscritos". Dos. En el art. 15 de la Constitución Política de Chile, actualmente en vigor, se dispone: "En las votaciones populares, el sufragio será personal, igualitario, secreto y voluntario".
}

33 Remito a la subsección IV.B. Quinto, donde describo el citado protagonismo jurídico. 
La calidad de colombiano enaltece a todos los miembros de la comunidad nacional. Todos están en el deber de engrandecerla y dignificarla. El ejercicio de los derechos y libertades reconocidos en esta Constitución implica responsabilidades. Toda persona está obligada a cumplir la Constitución y las leyes. Son deberes de la persona y del ciudadano: 1. Respetar los derechos ajenos y no abusar de los propios. 2. Obrar conforme al principio de solidaridad social, respondiendo con acciones humanitarias ante situaciones que pongan en peligro la vida $o$ la salud de las personas. 3. Respetar y apoyar a las autoridades democráticas legítimamente constituidas para mantener la independencia y la integridad nacionales. 4. Defender y difundir los derechos humanos como fundamento de la convivencia pacífica. 5. Participar en la vida política, cívica y comunitaria del país. 6. Propender al logro y mantenimiento de la paz. 7. Colaborar para el buen funcionamiento de la administración de la justicia. 8. Proteger los recursos culturales y naturales del país y velar por la conservación de un ambiente sano. 9. Contribuir al financiamiento de los gastos e inversiones del Estado dentro de conceptos de justicia y equidad.

En definitiva, la CPC 1991 distribuye, con generosidad, los derechos políticos. También prescribe un representativo caudal de deberes ciudadanos. La instauración constituyente la ejerce el Estado, aunque habita en el poder infinitesimal que dispone cada una de las personas que el respectivo orden positivo emplaza como ciudadano, con capacidad y vocación para la creación jurídica de la más alta estirpe, la Constitución y sus protocolos de variación.

\section{§ IV. Autoridad de la Constitución y su reforma}

\section{IV.A. Proposiciones dogmáticas}

1. Más arriba, en la sección § II, se mencionan los elementos del "Estado constitucional". Recuérdese la trilogía: el territorio, el pueblo y el poder. Sin embargo, la Constitución no puede 
pasar desapercibida, y no sólo porque su conocimiento es un apasionante y razonado debate del saber que la determina como objeto gnoseológico excluyente ${ }^{34}$, sino porque en la actualidad casi todos los Estados disponen de una Ley fundamental escrita. Efectivamente, al deslindarse los ámbitos de la autoridad y de la ciudadanía, la Constitución se incorpora como cuarto y nuevo elemento al sistema. La concepción de la Constitución como cuarto elemento del Estado significa un "programa" 35 , cuya comprensión teórica, en este momento, no se enfoca de modo directo hacia una escritura de una "identidad constitucional sudamericana", cuyo peso relevante o criterio rector residiese, eventualmente, en el discurso público originado por el Derecho de la Constitución.

La autoridad de la Constitución suministra una fuente de poder que, por su continuidad en el tiempo y su acatamiento $\mathrm{u}$ obediencia hasta cierto punto, puede constituirse en un elemento de estabilización de las expectativas ciudadanas. La autoridad de la Constitución permite fundar un poder estabilizado dentro del territorio del Estado y calculable en el tiempo; su misión mínima consiste en establecer un orden pacífico. Para alcanzar esa finalidad estelar, la Constitución instituye un orden.

34 Me refiero, básicamente, a la discusión permanente entre "neoconstitucionalistas" y "normativistas". Concretamente, el constitucionalismo puede ser conocido de dos maneras opuestas: como una superación del positivismo jurídico, en orientación tendencialmente iusnaturalista, o bien como expansión o perfeccionamiento de aquél. La primera concepción resulta etiquetada, por lo común, de "neoconstitucionalista". Por el contrario, se encuentra una concepción del constitucionalismo estrictamente "iuspositivista", entendiendo por "positivismo jurídico" un modelo de Derecho que reconozca como "Derecho" a toda combinación de normas puestas o producidas por quien está habilitado para producirlas, con abstracción o sin ligazón con sus contenidos y, por tanto, de su eventual injusticia o incorrección. V. Ferrajol, Luigi: "Constitucionalismo principialista y constitucionalismo garantista", ob. cit., pp. 11-17.

35 Peter HÄBERLE, en 1982, anunció su tesis, pieza a pieza, en Verfassungslehre als Kulturwissenschaft ("la Constitución como cultura"), Berlín. La tesis se reitera en "La Constitución en el contexto", Anuario Iberoamericano de Justicia Constitucional (AIJC), CEPC, Madrid, n 7 , 2003, pp. 223-225. Adviértase: en este escrito se resuelve deslizar a la Constitución como un "cuarto elemento", simplemente, sin ahondar en la inherente proyección "cultural" de la tesis del profesor alemán para nuestro "contexto" sudamericano. 
Dícese que tal institución de la autoridad constitucional define criterios perecederos porque valen merced a su propia imposición temporal y que regirán sus determinaciones en el espacio en que se desenvuelvan las existencias de los individuos de la comunidad respectiva.

2. Al idearse la primacía constitucional ${ }^{36}$ y su consecuente distinción jerárquica dentro del sistema de fuentes, seguramente se infirió que con la formulación de unas pocas palabras se generaba una suma regla, cualidad que merece ser comprendida en sus justos alcances: "suprema, altísima y que no tiene superior" ${ }^{37}$. Se emplaza una norma -la constitucional- en el sistema jurídico y se la posiciona como superior, porque ninguna será más alta que ella. Podría discutirse el don o gracia especial de la ubicuidad, es decir, si el emplazamiento y ulterior posicionamiento no constituyen, en rigor, una actuación autorreferencial de la propia norma constitucional que se determina a sí misma. Apréciese que el emplazamiento de la regla constitucional en función de su asignación como suprema, aunque tiene el fundamento en ella misma, no implica contradicción lógica, porque manejar con cuidado los enunciados de naturaleza autorreferencial es algo bien distinto que predicar que todo enunciado de ese tipo o naturaleza carezca de significado. ${ }^{38}$

36 Sobre la supremacía normativa de la Constitución, el texto jurídico con mayor antigüedad y aún en vigor reside en la determinación establecida en el art. VI, Sección 2 de la Constitución de EE. UU. de 1787: “Esta Constitución, y las leyes de los Estados Unidos que se expidan con arreglo a ella, y todos los tratados celebrados o que se celebren bajo la autoridad de los Estados Unidos, serán la suprema ley del país y los jueces de cada Estado estarán obligados a observarlos, a pesar de cualquier cosa en contrario que se encuentre en la Constitución o las leyes de cualquier Estado...". Basta pronunciar la fórmula normativa citada en voz alta para creer sobre la naturaleza todopoderosa de la suma regla, máxime al estimularse diversos aspectos que promueven su judiciabilidad, en el art. III, Sección 1: “Se depositará el poder judicial de los Estados Unidos en un Tribunal Supremo y en los tribunales inferiores que el Congreso instituya y establezca en lo sucesivo [...] Sección 2: El Poder Judicial entenderá en todas las controversias, tanto de derecho escrito como de equidad, que surjan como consecuencia de esta Constitución...".

37 Según DRAE, del latín summus.

38 El delicado problema teórico sobre la autorreferencia en el Derecho constitucional ha sido estudiado y expuesto en FerReYRA, Raúl Gustavo: Reforma constitucional y control de 
No hay misterio: para fundamentar la primacía de la regla constitucional, su cotización normativa descansa en su propio texto y no es preciso acudir a una norma superior a la Constitución misma para resolver la cuestión. La supremacía se comprende en normas emplazadas en la propia escritura de la Constitución; no hay ningún supuesto porque se trata de derecho constituyente puesto por el propio creador de la norma. Cotizarla como "suma regla" significa indicar su inherente "supremacía normativa" ${ }^{39} \mathrm{o}$ hacer referencia a su significación más armoniosa como "teorema de la supremacía" ${ }^{40}$. "Supremacía" tiene semejante significado que "suma": que no tiene superior en su línea, porque nada existe por encima de la regla fundamental del Estado.

3. El poder constituyente, integrado por los representantes de los ciudadanos que forman el pueblo del Estado, elabora y establece la norma constitucional, cuyo paso final, en ocasiones, también se remite a la aprobación del cuerpo electoral. En el momento constituyente de la creación jurídica originaria o en el momento constituyente de su variación, también se establecen las atribuciones para generar normas de rango inferior a la Constitución. Naturalmente, existirán en el orden normas de diverso rango, y el único modo conocido para mantener la unidad del citado ordenamiento exigirá que todas ellas que lo componen se reduzcan a la "unidad" de criterio prescrito por la Constitución.

constitucionalidad. Límites a la judiciabilidad de la enmienda, Buenos Aires, Ediar, 2007, pp. 437-450. Se remite en homenaje a la brevedad. Aquí sólo se sugiere la bibliografía básica sobre la cuestión: Ross, Alf: a) Sobre el Derecho y la justicia, Buenos Aires, Eudeba, 1994, pp. 80/82; b) "On Self Reference and Puzzle in Constitutional Law", en Mind, vol. 78, Issue 309, Oxford University Press, January 1969, pp. 1/24; HART, H. L. A.: "Self-referring laws", in Essays in Jurisprudence and Philosophy, Oxford, Clarendon Press, 1985 (reprinting of the first edition 1983), pp. 170/178, publicado originariamente en obra en homenaje a Karl Olivecrona, 1964; у с) Guibourg, Ricardo: "La autorreferencia normativa y la continuidad constitucional", en AA.VV.: El lenguaje del Derecho. Homenaje a Genaro R. Carrió, Buenos Aires, Abeledo Perrot, 1983, pp. 182/195; entre otros.

39 V. SAgüÉs, Néstor: Teoría de la Constitución, Buenos Aires, Astrea, 2004, pp. 98-99.

40 V. Ekmekdulan, Miguel Á.: Tratado de Derecho constitucional, t. I, Buenos Aires, Depalma, 1993, p. 31. 
Esta reducción a la unidad será entera y coherentemente posible si -y sólo si- existe una norma de la cual deriven su normatividad, de modo directo o indirecto, todas las otras demás normas del orden ${ }^{41}$. La unidad del orden jurídico estatal es una tarea fundamental que cumple la Constitución, al subordinar la producción y la realización jurídica a una determinada graduación de jerarquías, procesos y contenidos, en este último caso hasta cierto punto. La Constitución, al configurar el parámetro de validación formal y material, determina la membresía de las reglas inferiores de todo el orden estatal.

4. Elegir al artificio constitucional como fundamento del Estado constituye una determinación política. Se adopta con antelación a la arquitectura estatal y se funde con sus fines. Al desenvolverse la elección señalada, se "opera" entre la decisión política y la propia arquitectura del sistema "una relación circular" que rige "toda la construcción" futura ${ }^{42}$.

"Fundamento" se utiliza en varios sentidos y en múltiples contextos. Por amor a la claridad conceptual, entre la variopinta gama de significados, indico, a continuación, los elegidos. Así, "fundamento" en tanto "raíz" y "fundamento" en tanto "razón" son los senderos escogidos, en coincidencia con algunas de las alternativas lexicográficas. "Fundamentos constitucionales", en referencia a su raíz, porque toda la construcción jurídica de una comunidad, en determinado tiempo y espacio, queda o debe quedar sustentada, soportada, en fin, "fundamentada" por el propio Derecho que emana de la constitución, o cuya validación ésta autoriza. "Fundamentos constitucionales", en referencia a su razón, porque la validez jurídica de todo el Derecho de una comunidad, en determinado tiempo y espacio, queda o debe quedar explicada, justificada, en fin, "fundamentada" por el propio Derecho que emana de la constitución, o cuya validación ésta autoriza.

\footnotetext{
41 V. Boвbio, Norberto: Teoría general del Derecho, Bogotá, Temis, 1998, pp. 168-173.

42 V. Zaffaroni, E. Raúl et al.: Derecho penal, Buenos Aires, Ediar, 2000, pp. 104-105.
} 
5. La fundamentación constitucional del Estado se cumple por intermedio de cuatro principios o reglas: subordinación, variación, distinción y acción. Ninguna de estas reglas o principios posee una realización absoluta; por eso son reglas "inacabadas" o reglas de realización progresiva, o reglas de realización relativa. Estos cuatro principios o reglas que emanan de la Constitución pueden ser descritos como de terminación inacabada, porque por su intermedio se pretende fundamentar la regulación del Estado o la limitación de su inherente poder.

6. En su etapa de fundamentación estatal, cada uno de estos principios o reglas constitucionales se desenvuelve activamente, ya sea para configurar una raíz, ya sea para justificar una razón. Son "materiales estructurales", "pilares", o mejor, "elementos de la arquitectura del interior del Estado" emplazados positivamente, puestos en la Constitución. Sin embargo, para mantener incólume el rigor analítico, prefiero agruparlos en dos órdenes, exactamente parejos a los "fundamentos constitucionales". Más específicamente, pues, la regla sobre la variación o cambio y la regla sobre la subordinación caen dentro del marco de los fundamentos constitucionales, observados como raíz. En cambio, la regla sobre la distinción y la regla sobre la acción se corresponden, o mejor dicho, son la manifestación de los fundamentos constitucionales, apreciados, en este caso, como razón o justificación para el ejercicio de la fuerza estatal.

7. Dada la naturaleza de este escrito, según justifico en la "tesis primitiva" descrita en la sección I y la estrategia de argumentación planteada en la sección II, ahora menciono brevemente tres de esas reglas; más abajo, con mayor expansión y detalle, me concentro en la regla sobre la variación, porque -repito- constituye la materia de descripción y justificación en este texto. Así, las reglas sobre la fundamentación constitucional del Estado observan el siguiente contenido.

8. Para construir y mantener jurídicamente esa personalidad colectiva que se apoda "Estado", inevitablemente unos hombres tendrán que dar órdenes, encontrarse facultados para mandar con atribuciones suficientes, y otros deberán obedecerlas, ya sea 
por leal convicción, o por otro motivo que influya y determine el estado de dominación. El poder se distingue en "constituyente" y "constituidos": Derecho constituyente y Derecho constituido. La Constitución y su reforma es producida y concretada en los "momentos constituyentes"; el resto de las reglas jurídicas de alcance general son creadas por el Congreso federal o el departamento ejecutivo; excepcionalmente, por el poder judicial.

En el seno de la Constitución, la división horizontal del poder tiene lugar en la casa republicana: departamentos precisos, con atribuciones excluyentes y bien determinadas, que se encargan de la producción o realización del Derecho. La división vertical del poder tiene lugar ya sea por la vía del federalismo o del unitarismo; Brasil y la Argentina, por ejemplo, son modelos federales. Colombia, Chile, Paraguay, Uruguay y Ecuador instituyen modelos unitarios.

La división del poder -en constituyente y constituido, o en horizontal y vertical- constituye la regla organizativa fundamental en el Estado constitucional. Dentro del marco propiciado por la regla de distinción de funciones, se genera la ilusión de que no debería existir fuerza desregulada; empero, todos saben que allí donde existe un poder puede existir, también, un servidor dispuesto a ejercer una fuerza estatal no disciplinada por normas jurídicas. Porque allí donde existe un poder constituido, usualmente, existe un servidor público bien decidido a su abuso y corrupción, por la violación del orden de cosas constitucionales instituido o por apelación al estado de excepción o emergencia.

9. Las Constituciones pretenden sostener y conferir validez a los órdenes jurídicos que se generan a partir de ellas. Todas las Constituciones tienen un legajo importante o inmenso de derechos y bienes fundamentales a los que se les confiere reconocimiento. Los derechos y bienes fundamentales insertados en las Constituciones son líneas significativas para la acción estatal y la ciudadana ${ }^{43}$. Concebir de este modo a los derechos

43 Las tesis sobre los derechos fundamentales como directivas básicas del orden jurídico fue adelantada y desarrollada en FerReYra, Raúl Gustavo: “Enfoque sobre el mundo jurídico. 
fundamentales significa que ellos son derechos subjetivos; sin embargo, también son normas objetivas del orden jurídico estatal que lo disciplina e intenta sostenerlo. La comprensión objetiva de los derechos fundamentales los emplaza, objetivamente, como líneas de acción que deben asegurar un uso correcto de la fuerza estatal para la consecución, el mantenimiento y el desarrollo de una coexistencia comunitaria en paz.

10. La regla sobre la subordinación jurídica del Estado por intermedio de cada uno de los despliegues que la Constitución dispone (supremacía normativa; relación con el Derecho internacional de los Derechos Humanos -DIDH-; control de constitucionalidad y rigurosa juridicidad) persigue establecer la certeza, es decir, el "conocimiento seguro" por parte de la ciudadanía y los servidores públicos sobre la determinación del campo dominado por el Derecho y del otro campo libre, un mundo sin reglas jurídicas. ${ }^{44}$

Con los alcances de sus prescripciones jurídicas, inevitablemente, hacen presuponer o representar que la certeza en el mundo estatal -pasado, presente y sobre todo porvenir- queda afianzada, se encuentra ligada, en fin, subordinada a una regla artificial: la Constitución, que no tiene nada de orden metafísico. La certeza siempre es "de alguien respecto de algo" ${ }^{45}$; en nuestro caso, nada más y nada menos que del hombre sobre el orden jurídico que fundamenta al Estado.

IV.A.bis. Proposiciones dogmáticas. Continuación del asunto. Regla sobre la variación

La regla sobre reforma o variación de la Constitución es un fundamento del Estado, al igual que la regla sobre la distinción

Constitución y Derechos Fundamentales", en Academia. Revista sobre enseñanza del Derecho, año 11, n² 21, Buenos Aires, Facultad de Derecho, Buenos Aires, 2013, pp. 243-282.

44 La tesis sobre "la juridicidad, raíz del orden estatal" ha sido desarrollada en FerreYRA, Raúl Gustavo: Manifiesto sobre el Estado constitucional: reglas fundamentales sobre raigambre y justificación de la mancomunidad Estatal, Medellín, Ediciones UNAULA, 2017, pp. 117-146.

45 Bunge, Mario: Diccionario de Filosofía, “Certeza”, México D.F., Siglo XXI, 2001, pp. 213-214. 
de funciones, la regla sobre subordinación y la regla sobre la acción de los derechos fundamentales. Brindo, a continuación, diez ideas básicas sobre el estado de cosas que promueve el acto reformatorio de la Ley fundamental.

Primera. Toda Constitución debería contener como base de certidumbre que su escritura metódica sólo podrá ser expandida, contraída o revisada, por el propio proceso detallado en su texto. Podría entenderse, no sin razón, que el cambio o la variación constitucional atraparía a todos los sucesos y procesos que pueden sufrir los textos constitucionales en el tiempo. No obstante, rigurosamente, aquí el cambio sobre el que se teoriza es el "cambio formalizado" o la "variación" del sistema normativo constitucional, que implica la modificación de su texto producida por acciones razonadas por su autor y regladas por la propia suma regla del orden jurídico.

La reforma constitucional puede darse de tres maneras: a) por expansión: cuando se agrega una nueva regla a la combinación constitucional originaria; $b$ ) por contracción: cuando se elimina alguna regla de la nómina de esa combinación constitucional; y c) por revisión: cuando se elimina en la combinación constitucional alguna regla y luego se agrega otra incompatible (total o parcialmente) con la eliminada. ${ }^{46}$

Segunda. Cada orden jurídico estatal regula y establece, con sus propios matices, el proceso de reforma. Sin embargo, en los procesos de reforma deberían participar todos los ciudadanos y elegir a sus representantes y, en modo eventual, aprobar las normas elaboradas por el órgano constituyente, como así

${ }^{46}$ Cfr. Alchourrón, Carlos: "Conflictos de normas y revisión de sistemas normativos", en Alchourrón, Carlos y Bulygin, Eugenio: Análisis lógico y Derecho, Madrid, Centro de Estudios Constitucionales, 1991, p. 301. Por lo pronto, en este marco, la teoría del cambio constitucional es la teoría de la reforma constitucional. Por ende, queda fuera cualquier otra circunstancia que, como una revolución, quebrantamiento o ruptura, o una mutación, no pueden ser objeto de proyección como un "procedimiento formal de aprobación", tal como conceptúa Peter HäBERLE respecto de la reforma ("Desarrollo constitucional y reforma constitucional en Alemania", en Pensamiento Constitucional, Perú, Pontificia Universidad Católica del Perú, Fondo Editorial, 2000, Año VII, p. 17). 
también fijar los órganos constitucionales y constituyentes determinados, de manera respectiva, para proceder a la variación normativa. Justificadamente, pues, la reforma configura un fundamento notable que sustenta la certeza en la edificación continua del orden jurídico del Estado.

Fuera de la canalización dispuesta en la Constitución, no debería aceptarse nunca ningún cambio, ni considerarse autorizado. Porque la propia autoridad de la Constitución no debería tolerar cambios fuera del proceso prescrito en ella como suma regla. El cambio es una posibilidad enorme en la vida de los hombres. Arraigar, entonces, el cambio constitucional a un proceso clave e indisponible consagrado, en modo autorreferente, también confiere certeza en las relaciones humanas. De este modo, el proceso de variación de la Ley Mayor constituye un fundamento del Estado. Cambiar, con arreglo a reglas predispuestas, disuelve la ley del más fuerte o la fuerza bruta que, conjunta o separadamente, desalientan cualquier proceso de pacificación por la violencia congénita y sin regulación que portan y transmiten.

Sin embargo, obsérvese que las bases que surgen de las previsiones sobre reforma constitucional no eliminan la irracionalidad de gobernantes con ínfulas totalitarias o de aquéllos que, por dolo o negligencia, subvierten la democrática "alternancia" y la pervierten por una "liquidación" abyecta y a precio de remate de la forma de gobierno republicana.

Tercera. La Constitución, con sus esquemas para la regulación de conductas, no abarca absolutamente todos los comportamientos humanos. Juzgar de ese modo sería, cuanto menos, extravagante e impropio, porque la Constitución determina un campo dominado por el Derecho; pero, fuera de él, hay otro campo libre, un mundo sin reglas jurídicas.

Cuarta. La Constitución debe ser susceptible de cambio o variación para resguardar su fuerza normativa ante múltiples y cambiantes circunstancias históricas, sin por ello alterar su propia identidad. Los ciudadanos que integran el pueblo del Estado, 
por intermedio de sus representantes, son los sujetos que deben disponer del derecho político a cambiarla o modificarla cuando, en libre y democrática decisión política fundamental, consideren oportuno y necesario disponer la producción de la más alta estirpe jurídica. Por eso es preferible pensar en reformar la Constitución toda vez que se pueda determinar que ello sea necesario, conveniente y oportuno, y no deformarla mediante interpretaciones jurisdiccionales que la vuelven sin sentido, al desnaturalizar (según los casos, de modo parcial o completo) las pretensiones de normatividad emergentes de sus reglas.

Las palabras que componen la lengua del Derecho constitucional son "irreversibles" ${ }^{47}$; una vez que los hombres las han escrito, pueden aumentarlas, revisarlas o reducirlas; empero, intuir su anulación resulta complejo porque no se puede utilizar una goma de borrar, salvo que se creyese en la existencia de "dioses supremos" que puedan generar el artificio para reglar las existencias ciudadanas en la comunidad. Por consiguiente, la Constitución -como verdadera máquina del tiempo- garantiza su propia capacidad evolutiva por la vía de su protocolizada reforma. La existencia de los seres humanos, en pleno siglo xxI, se encuentra desbordada, sin cesar, por invenciones constantes, sucesivos descubrimientos y actualizaciones permanentes. Frente a tal panorama, la codificación contenida en la Ley fundamental no debería quedar arrinconada en las palabras de seres humanos que han muerto o que no militan en la vida política activa. La tarea de reformar posibilita el cambio o variación a cada generación de ciudadanos vivos, al recoger una adaptación o promover un estímulo para la vida política de la comunidad, con verdadera conciencia de que esta o aquella variación es la vía idónea para perfeccionar la paz y promover el bienestar general.

Quinta. El poder de reformar la Constitución, siempre sometido a reglas de competencia prefijadas, es un poder

47 Barthes, Roland: El susurro del lenguaje. Más allá de la palabra y la escritura, Buenos Aires, Paidós, 2015, p. 115. 
político porque crea Derecho constitucional. El cambio constitucional que produce variaciones sustantivas en el texto tiene una peculiaridad: siempre forma algo nuevo, la Constitución reformada; así, la reforma por expansión o contracción o revisión del sistema genera una nueva combinación de reglas.

Sin mayores esfuerzos, puede decirse que si la Constitución política estatal es la decisión de los ciudadanos que integran pueblo, la reforma también debe serlo. Ergo, el plan constitucional debe ser decidido por su creador: el cuerpo electoral que debe escoger a sus representantes en comicios abiertos, auténticos y transparentes.

Hasta el momento, el único modo conocido para no temer al cambio político consiste en aceptar los "procesos formales de aprobación", que atribuyen una variación reglada, limitada y detallada al campo de las reglas constitucionales. Ese proceso de reforma constitucional puede favorecer la adaptación de cambios en ciernes o alentar el desarrollo de nuevos itinerarios jurídicos.

Sexta. Escribir, al igual que hablar, siempre implicará, al menos, una descripción o una valoración. Muchas veces, el hecho de la repetición doctrinaria de un término sugiere una apariencia fantasmal o anula una evaluación rigurosa. El propio proceso de cambio que las leyes fundamentales se "dedican a sí mismas" -singular propiedad atribuida a las Constituciones- se encuentra en dicha galería. No deseo ser hereje, pero no es el término "rigidez" el más afortunado para advertir que la Constitución no debe ser reformada o cambiada por intermedio de los procesos semejantes a los previstos a la producción jurídica de rango inferior a ella. Para no recibir acuse de falta de religiosidad dentro del constitucionalismo, se prefiere mantener el empleo de determinada "rigidez", suficientemente extendido en la doctrina de los autores. Si fracasa la rigidez de la suma regla constitucional, fracasa el escalonamiento jerárquico y, con este último fracaso, no hay lenguaje posible para la unidad del sistema estatal.

Alentar un proceso cierto para la reforma implica asumir "determinada rigidez" para el cambio constitucional. "Determinada rigidez" significa, por lo pronto, que la Ley fundamental no 
debería ser reformada sobre la base de mecanismos semejantes a los previstos para la elaboración de la legislación ordinaria o, mejor dicho, que no debería ser cambiada por procesos idénticos a los pautados para la producción de normas de rango jerárquico inferior al determinado de manera autorreferente por la suma regla para ella misma. Esta "determinada rigidez" es consecuencia directa, sin intermediaciones, del principio de supremacía de la Constitución. El hecho de que las Constituciones contemplen la jerarquía constitucional, o a veces el rango superior o equivalente del DIDH en el sistema de fuentes, no significa el abandono ni de determinada rigidez constitucional ni de una particular forma de producción del sistema jurídico constitucional.

Séptima. Que la Constitución determine un proceso extraordinario para su metamorfosis se liga con su peculiar naturaleza intangible. La intangibilidad fuerte o precaria indica la presencia de una propiedad primaria u objetiva ${ }^{48}$ destacadísima en su ontología; sin embargo, esa cualidad "no puede hacer que lo sucedido no haya sucedido" (aunque puede dejar intactos determinados estados de cosas o "censurarlos de modo categórico" $\left.{ }^{49}\right)$. Por esa razón, sólo puede penetrar el "presente y el futuro" ${ }^{\circ}$, que se encuentran abiertos al Derecho constitucional; no el pasado ${ }^{51}$. El tiempo futuro, por su parte, no puede

\footnotetext{
48 Bunge, Mario: A la caza de la realidad, Barcelona, Gedisa, 2007, pp. 68-70.

49 Una pieza de esta naturaleza jurídica se ofrece en el art. 16 de la CFA, según texto de 1853, actualmente en vigor: "En la Nación Argentina no hay esclavos: Ios pocos que hoy existen quedan libres desde la jura de esta Constitución; y una ley especial reglará las indemnizaciones a que dé lugar esta declaración".

50 Englsch, Karl: El ámbito de lo no jurídico, Córdoba (España), Universidad Nacional de Córdoba, 1960, p. 15.

51 Pese a que no conmueve lo afirmado en el cuerpo principal respecto a la naturaleza incólume del pasado, en el proyecto de reforma constitucional chileno, iniciado en mensaje de la Presidenta de la República, Michelle Bachelet, para modificar la Constitución Política de la República, se puede leer la siguiente propuesta de Preámbulo: "Nosotros, los pueblos de Chile, responsables ante nuestra historia y su porvenir, nos otorgamos esta Constitución Política de la República de Chile...". Boletín № 11.617-0, Mensaje 407-365, Santiago de Chile, 6/3/2018.
} 
quedar ligado eternamente al Derecho constituyente del Estado, porque la ausencia de cambio es impropia del itinerario de los seres humanos. El dictado de reglas jurídicas eternas, aunque encomiable, instituye una definición que no resulta compatible con la finitud del ser humano. Todo intento de hacer totalmente irreformable el futuro jurídico chocará, por un lado, con la naturaleza cambiante del pensamiento de los hombres y, por otro, con su natural entidad física y perecedera.

Octava. En el Estado constitucional no sólo los servidores públicos sino todos sus ciudadanos deben ser "guardianes" 52 de la Ley fundamental, porque la suma regla instaura las reglas para el desarrollo y el cambio del proceso político comunitario, en el que todos -de una manera u otra- se deberían comprometer. La limitación de las reformas constitucionales, por la vía de las "cláusulas de eternidad" 53 , camino para resguardar determinada identidad del "Estado constitucional", quizá debiera ser entendida, en América del Sud, a partir de la comprensión de sus semánticas constituyentes, como referida a las concepciones de "república" y la "democracia".

Entiendo a la "democracia" 54 como regla conceptual que indica una "forma política de Estado" en la que la capacidad

52 HÄBERLE, Peter: El Estado constitucional, ob. cit., p. 286.

53 Ibíd., p. 288.

54 Exactamente, "democracia política": un modelo de producción y realización del orden del Estado. Por una cuestión de claridad, evito el adjetivo "política", aunque a ella me refiero. Recuérdese, además, la comprensión expuesta en la sección II: estas escrituras solamente poseen vocación normativa. No se hace un examen de la realidad política de ninguno de los países. Así, por ejemplo, no hago alusión a las tendencias articuladas hacia una "dictadura electiva" (MARQuARDT, Bernd: Los dos siglos de Estado constitucional en América Latina (1810-2010), ob. cit., p. 186), ni a sus perversiones que rigieron al menos desde 1948 en Colombia hasta la CPC 1991. Tampoco aludo al proceso de paz con las FARC, actualmente en ciernes, que trata de apagar el conflicto bélico que ha cobrado decenas de miles de víctimas durante más de 70 años de guerra fraterna. En el cuerpo principal del texto describo la "democracia" normativamente inferida como un contenido irreformable de las Constituciones en América del Sud. Ese camino implica evitar cualquier otro derrotero. El Derecho constituyente se encuentra en el mundo, forma parte de la realidad, a la que trata de adaptarse 0 transformar. Muchas veces la política ni se adapta ni se transforma con la fuerza normativa de la Constitución. Sin que implique desvío de mi "Estrategia argumentativa" planteada en 
para decidir pertenece por igual a todos y cada uno de los ciudadanos que integran el pueblo. Ingresada la democracia al cauce de la Constitución, aquella soberanía popular es ejercida en forma representativa, sobre la base del principio de la mayoría y respeto de la minoría. Si bien el principio mayoritario es la base de la democracia, no debe ser entendido en sentido absoluto, puesto que ninguna mayoría debería negar los derechos de la minoría, en especial, sus derechos de libertad, políticos, sociales y civiles no patrimoniales.

Las Constituciones fundamentan normativamente la juridicidad del Estado. Por ello, un Estado que titubee o carezca del poder para garantizar la plenitud de la producción democrática en su propia dimensión constitutiva ofrecería un modelo con bajísima intensidad en su ciudadanía plena; mejor dicho, una ciudadanía en sentido parcial.

Desde fines del siglo $\mathrm{xx}$, la democracia como forma de orientación política del Estado, gracias a la fina distinción de Guillermo O'Donnell, puede ser comprendida como representativa o institucionalizada, y delegativa o no institucionalizada ${ }^{55}$. En la enorme mayoría de los países de América del Sud, las democracias constitucionales son representativas en sus letras jurídicas fundadoras; es decir, queda institucionalizado que el cuerpo electoral elige a ciertos y determinados servidores públicos y estos últimos hablarán por aquéllos y tomarán decisiones para la gobernanza comunitaria. La palabra de la comunidad queda

\footnotetext{
la sección II, y para no eludir las fallas que emergen de la propia impronta colombiana en su política, transcribo las últimas palabras de Carlos Gaviria: "No aceptemos que Colombia es una democracia, Colombia es una sociedad que tiene vocación democrática en el sentido de que además la comuniquemos, la contagiemos a través de la educación, pero esta no es una democracia... Hay que ser realista. Cuando yo digo 'esta no es una democracia' no estoy execrando a la sociedad colombiana sino que estoy situándola de acuerdo con mi percepción de donde debe estar. Es una democracia por construir, es una democracia germinal y para construir esa democracia el primer ingrediente es la educación". V. GaviRIA Díaz, Carlos: "¿Cómo educar para la democracia?", Bogotá, Cuadernos Ex Libris, Escuela de Maestros Gimnasio Moderno, 2015, p. 28.

55 O'Donnelt, Guillermo: Contrapuntos. Ensayos escogidos sobre autoritarismo y democratización, Buenos Aires, Paidós, 1997, pp. 287-304.
} 
en la esfera representativa de los servidores públicos, porque la deliberación que implicaría una democracia directa resulta una ponderación inviable. Se espera que los representantes de los ciudadanos, en todo el cielo estatal, elaboren decisiones racionales y que ellas sean escrutadas por controles de todo tipo, porque existirían instituciones fuertes para hacerlo. La consabida responsabilidad política y jurídica del decisor constituye una figura cenital del modelo.

Al fundarse las repúblicas sudamericanas, en pleno siglo XIx, existían solamente tres modelos racionales para ordenar el sistema de gobierno: el presidencial, el parlamentarismo británico y el monárquico constitucional europeo ${ }^{56}$, siempre que se juzgase fuera la bruta irracionalidad de cualquier autocracia. Casi todos los países de América del Sud han copiado el modelo presidencial inventado por la Constitución de los Estados Unidos de 1787. Al cabo de 200 años, también lo han deformado y devaluado. Hay un fruto silvestre que nace y se desarrolla en la región sudamericana: la democracia delegativa. Ella se aprovecha del ambiente del presidencialismo ${ }^{57}$ para disponer de un hábitat inherente para desgarrar ciudadanía, aunque no supone ni un desagradable aviso de retorno a la autocracia, ni por cierto un encomiable progreso encaminado hacia una democracia más abierta y decididamente plural.

La democracia delegativa hace pie en el hecho de que una persona ganará la elección presidencial porque es "fuertemente individualista" 58 . Tal ciudadano creerá sentirse autorizado a gobernar como le plazca. Quizá tenga una restricción: la realidad emergente de las relaciones de poder y la limitación constitucional del término de su representación, que, en caso

\footnotetext{
56 V. Valadés, Diego: "Formación y transformación del sistema presidencial", en AA.VV.: Ius constitutionale commune en América Latina. Rasgos, potencialidades y desafíos, México, D.F., IIJ, UNAM, 2014, p. 185.

57 Probablemente, los líderes de la Independencia, en América del Sud, obraron de tal modo porque la forma republicana no encajaba con los otros modelos y el contexto institucional del neonato "Derecho constitucional comparado" no mostraba muchas más opciones.

58 O’DonnelL, Guillermo: Contrapuntos... ob. cit., p. 294.
} 
de existir, siempre tratará de ser reformada hacia un modelo eterno o más o menos vitalicio ${ }^{59}$.

La democracia delegativa se desarrolla con bravura en el presidencialismo. La gobernanza del presidente no necesitará guardar congruencia con anuncios realizados en la campaña electoral. Una vez elegido el presidente en el ámbito de una democracia delegativa, en general bajo el absolutismo de las pasiones, es esperable que los delegantes-ciudadanos constituyan complacientemente una audiencia pasiva de todo lo que haga el presidente. De allí hasta un estilo mágico de hacer política hay solo un paso, o quizá no lo haya, porque el mandato delegativo asume, en su mismidad, dicha naturaleza genuina. En la lógica de la delegación, la despolitización de la ciudadanía es un acto típico, en virtud de que el presidente cree que él y no otro es un delegado, el único de un electorado cuya providencia alumbrará con su inteligencia para siempre. Casi un hecho divino. Para muchos presidentes en América del Sud, por tanto, el "optimismo" sobre su gestión se puede insinuar con el siguiente discurso: "lo bien que está todo cuando manifiestamente todo está muy mal"60.

En los escenarios de democracia delegativa, los partidos políticos, las organizaciones no gubernamentales, el Congreso, los servicios de comunicación audiovisual y el auditorio ciudadano son libres, desde luego. Sin embargo, pueden constituir un estorbo u obstáculo a la tarea del presidente, quien en su carrera hacia el absolutismo cree reunir el destino u horizonte del país. La diferencia radical entre "democracia delegativa" y "democracia representativa" es la debilidad de los controles (horizontales y verticales) y de las instituciones políticas, en particular: una jurisdicción sumisa. La red de controles que puedan examinar y cuestionar no es puesta en funcionamiento o, cuando se ejecuta, es extremadamente débil ${ }^{61}$.

\footnotetext{
59 Ibíd., p. 293.

60 Roa Bastos, Augusto: Yo el supremo, Buenos Aires, Eterna Cadencia, 2017, p. 193.

61 O'Donnell, Guillermo: Contrapuntos... ob. cit., p. 295.
} 
Reconozco -reitero- que la democracia delegativa no es autocracia, pero no permite la institucionalización plena de una democracia abierta y plural. Además, hay un elemento crucial en este modelo: el líder elegido, casi siempre en comicios auténticos y bastante transparentes, juzga contar desde el inicio con una legitimación para convertirse en el realizador de la más inspirada obra en beneficio de la comunidad. Hay un pecado original en la democracia delegativa que la condena para siempre: su negación del debate plural. Al encerrar la institucionalidad básica en las modestas razones y pasiones de un solo hombre, su resultado fatal sólo es cuestión de tiempos. Jamás un presidente será capaz, en su singularidad, de encontrar y desarrollar la más robusta distribución de las bendiciones existenciales para los ciudadanos que integran una comunidad.

Si la democracia es un obrar de los ciudadanos, en el concepto de "república" halla su casa; en sentido constitucional, la posibilidad de vivir en libertad y en el seno de una sociedad abierta. Para ser vivida, la república, como "forma de gobierno", debe mantenerse abierta la posibilidad de que existan iniciativas robustas y alternativas pluralistas semejantes. Sin división de poderes, sin comicios auténticos, con ausencia de publicidad de actos de gobierno, con servidores irresponsables y sin estricta periodicidad de funciones, resulta imposible explicarlo, porque las indivisiones, el despotismo, la inidoneidad, los secretos y la falta de alternancia inhiben e impiden a cualquier minoría oponerse u enfrentar radicalmente cualquier pretensión mayoritaria.

Novena. Mediante la reforma, el artificio constitucional afianza la estructura del Estado, al permitir cambios en la regla suprema, que, por cierto, nunca será copia ni imitación de ningún ente u objeto perfecto e ideal. Por eso corresponde habilitar la propia metamorfosis de la Constitución, proceso que tendrá límites determinados en la suma regla del orden estatal. La vulneración de esos límites determinados para la reforma indicará que el "nuevo" orden instituido dejará de ser comprendido como una secuencia del normas del "viejo orden", en el cual la unidad de esta secuencia, y con ello la identidad de ese orden jurídico 
(el viejo), estaban dadas por la identidad y el cumplimiento de los criterios por él ordenados para identificar las normas de la secuencia: el contenido de la regla de reconocimiento constitucional que autorizaba el cambio, ahora violentada por el nuevo orden. La violación de los límites, pues, establece un nuevo modelo jurídico, el que no puede peticionar para sí la cadena de validez con el anterior; transgredir los límites, en principio, da lugar a dos modelos jurídicos constitucionales, el abolido y el abolicionista.

El poder constituyente reformador, cuya función propia es instaurar un nuevo conjunto de disposiciones constitucionales que mantiene la secuencia de validez, se encuentra diseñado, con diferentes modelos en los diferentes textos constitucionales. No obstante, todos esos procesos poseen un denominador orientador en común: prohijar la producción constituyente, la creación de normas constitucionales.

Cada uno de esos procesos contiene -siempre- determinadas etapas, insustituibles, enmarcadas en la Constitución. Por lo general, además, una relación ontológica esencial une las etapas del proceso reformador con bastante nitidez. Las etapas del proceso constituyente conforman un todo, el propio proceso reformador de la Constitución. También, por regla, cada uno de los actos cumplidos en el ámbito del proceso reformador posee relevancia superior a los actos cumplidos en la órbita de los poderes constituidos ordinarios y cotidianos. Por lo tanto, un determinado proceso reformador de la Constitución será válido, formalmente, si ha satisfecho todos los requisitos fijados en cada una de las etapas previstas para el cambio, esto es, su segura, propia y radical secuencia de validación normativa. Mucho más complejo resulta definir la irregularidad por violación de límites materiales (sobre la inconstitucionalidad de una reforma y su control, remito a la sección IV.C).

Décima. La experiencia demuestra que muchas veces se realizan "cambios políticos" sin apelar al proceso de reforma constitucional. Además, por la fuerza normativa de lo fáctico, tales cambios políticos, muchas veces, desgraciadamente, se 
imponen y causan una herida sangrienta en el orden estatal. El cambio constitucional aquí teorizado sólo se puede configurar por el proceso de reforma previsto en la Ley fundamental. Respecto de esto último, podría argüirse que se trata de un dogmatismo caprichoso. No es así, porque la Constitución constituye la "clave de la confianza" 62 de la política comunitaria; fuera de sus canales, sólo corresponderá aguardar la ausencia de control, ergo, la devaluación tajante de toda su capacidad procesal regulativa y, por ende, el camino sin señales ni contenciones hacia la anarquía más desviada.

Entonces, prescindir del Derecho para producir cambios políticos en la más alta cumbre de la ordenación se compadecerá, quizá, con actos del poder político y se identificará con la pura fuerza emanada de la voluntad. En otras palabras y más directamente: podrá clamarse que tengan contenido jurídico, pero no serán Derecho constituyente del Estado constitucional porque carecerán de su razonada conjugación elaborada.

\section{IV.B. Justificación del asunto}

De acuerdo con la propuesta trazada en la sección II, ahora corresponde examinar la CPC 1991.

Primero. La Constitución colombiana en vigencia fue sancionada y publicada en julio de $1991^{63}$. Desde entonces ha

\footnotetext{
62 ValAdÉs, Diego: "Todo cambio es constancia. Apuntes para una reforma constitucional”, en AA.VV., El significado actual de la Constitución. Memoria del simposio internacional, México, D.F., UNAM, 1998, p. 557.

63 Todos los Estados sudamericanos tienen uno o varios autores que pertenecen o han pertenecido al movimiento literario denominado "realismo mágico". En 2018 se cumplen 70 años desde que el término, probablemente, fue utilizado por Arturo Uslar Pietri en su ensayo "El cuento venezolano", en la obra Letras y hombres de Venezuela (Madrid, Editorial Mediterráneo, 1978, p. 287): “Lo que vino a predominar en el cuento y a marcar su huella de una manera perdurable fue la consideración del hombre como misterio en medio de los datos realistas. Una adivinación poética o una negación poética de la realidad. Lo que a falta de otra palabra podría llamarse un realismo mágico". A su vez, en 2017 se cumplieron los primeros 50 años de la salida de las prensas de la mágica novela de Gabriel García Márquez: Cien años de soledad. La "congregación del realismo mágico" configuró, quizá, un movimiento y acaso una teoría literaria; empero, en todos nuestros Estados se desarrollan sucesos
} 
sido reformada en reiteradas oportunidades -aunque Colombia posee y padece un mecanismo de "declaración de inexequibles" de las enmiendas en la sede de la Corte Constitucional de Colombia (CCC)-, sin desvanecer ni devaluar las prescripciones originarias de los principios y las reglas que la nutren y desarrollan en las 380 piezas de su articulado gestado con naturaleza permanente.

En su cabecera se emplaza el "Preámbulo"64. Luego, sus trece Títulos, a saber: I. "De los principios fundamentales"; II. "De los derechos, las garantías y los deberes"; III. "De los habitantes y del territorio"; Iv. "De la participación democrática y de los partidos políticos"; v. "De la organización del Estado"; vI. "De la rama

dignos del género literario, que se inspiran en él o lo superan. Los actos de elaboración, sanción y publicación de una Constitución son decisivos y determinados sobre un objeto mundano, motivo por el cual podrían ser perfectamente narrados y ubicados en el tiempo y en el espacio. El Secretario General de la Asamblea Constituyente dice que la CPC 1991 no fue "sancionada" por la Asamblea "como cuerpo deliberativo sino por los constituyentes reunidos, informalmente, en ceremonia solemne" la noche del 4/7/1991, "sin que aún existiera la codificación del articulado aprobado reglamentariamente por la dicha Asamblea". La publicación del "cuerpo básico" se realizó, en la Gaceta Constitucional, número 114 del 7/7/1991. Luego, el 20/7/1991, en el número 116 de la Gaceta Constitucional, se publicó una "recodificación" que superó omisiones e imperfecciones de la publicación del 7 de julio. V. Pérez Escobar, Jacobo: Derecho constitucional colombiano, Bogotá, Temis, 1997, p. 9. Finalmente, el 10/10/1991 se cumplió una nueva publicación, en la Gaceta Constitucional, número 127. Según se infiere, esta última contiene el texto utilizado en esta investigación para su exegesis y comentario. Entiendo que significaría un error básico que los colombianos imaginen que los acontecimientos narrados solamente pueden suceder sobre su benigna tierra, bajo su generoso sol y en el marco de su magnífico ambiente natural y social. El realismo mágico abraza a todos nuestros países. Por lo demás, la CPC 1991 contiene una regla de clausura del orden jurídico en su art. 380: "queda derogada la Constitución hasta ahora vigente con todas sus reformas. Esta Constitución rige a partir del día de su promulgación".

64 Las doctrinas de los autores en los países de América del Sud difieren en la cotización de los preámbulos constitucionales. Así, en la Argentina existe un consenso extendido respecto de su naturaleza normativa; en cambio, en Brasil no se le otorga valor prescriptivo. Desde la doctrina judicial, la CCC ha destacado el poder vinculante del Preámbulo, en tanto sustento del orden que propiamente instaura la CPC 1991. Por tal razón, toda norma que desconozca cualquiera de los fines en él señalados lesiona la Constitución porque traiciona sus principios. Además, los magistrados de la CCC también han sostenido que la declaración del Preámbulo forma "parte integrante" de la CPC 1991. V. Sentencia C-479/92, 13/8/1992, disponible en http://www.corteconstitucional.gov.co/relatoria/1992/c-479-92.htm, consultada por última vez el 25/5/2018. 
legislativa"; vII. "De la rama ejecutiva"; vIII. "De la rama judicial"; Ix. "De las elecciones y de la organización electoral"; x. "De los organismos de control"; xI. "De la organización territorial"; xII. "Del régimen económico y de la hacienda pública" y xiII. "De la reforma de la Constitución". Finalmente, las "Disposiciones transitorias" se articulan en más de 60 piezas no permanentes; esta colección ha crecido en cantidad de palabras con los actos legislativos 1/2016 y 1, 2 y 3 del 2017, por intermedio de los cuales se establecen diversos instrumentos para la terminación de una "guerra sin nombre" y construir una paz estable y duradera.

Segundo. La CPC 1991 es una Ley fundamental concebida globalmente, poseedora de innovaciones en materia de organización política, social, económica y cultural, aunque no modificó el sistema de gobierno "fuertemente presidencialista"65. Las innovaciones económicas, sociales, políticas y jurídicas se hacen sentir desde el Preámbulo hasta las disposiciones transitorias. En sus 27 años de vida ha sido reformada por más de 45 actos legislativos que han diseminado, a su vez, cambios en 100 de sus artículos permanentes o transitorios.

La CPC 1991 posee funciones de carácter político (cauce procesal para la formación de la decisión del Estado), jurídico (regla fundamental de la comunidad) y simbólico (paradigma del pluralismo de la sociedad). También cumple una interesante función "pedagógica" 66 . Así, pues, en el artículo 41 se ordena:

En todas las instituciones de educación, oficiales o privadas, serán obligatorios el estudio de la Constitución y

\footnotetext{
65 Bushnell, David: Colombia. Una nación a pesar de sí misma. Nuestra historia de los tiempos precolombinos hasta hoy, Bogotá, Planeta, 2003, p. 393.

66 Desde el punto de vista normativo, la simiente proviene, muy posiblemente, del art. 377 de la Constitución de Francia de 1795: “El pueblo francés deposita la presente Constitución en la fidelidad del Cuerpo legislativo, del directorio ejecutivo, de los administradores y jueces; a la vigilancia de los padres de familia, a las esposas y a las madres, al efecto de los jóvenes ciudadanos, a la cordura de todos los franceses". Desde la dogmática científica, la obra de Peter Häberle, Cartas pedagógicas a un joven constitucionalista (Niedersachsen, Alemania, European Research Center of Comparative Law, 2013) constituye una obra erudita, original y francamente fundamental en la instrucción y educación del Derecho constitucional.
} 
la Instrucción Cívica. Así mismo se fomentarán prácticas democráticas para el aprendizaje de los principios y valores de la participación ciudadana. El Estado divulgará la Constitución.

Esta naturalización de la función pedagógica indicaría que la lengua constitucional podría inducir a todos los seres humanos a quienes obliga a realizar una comprensión estudiada de su escenario lingüístico, con el objeto de desarrollar el dominio individual que cada uno de ellos podría disponer sobre la realidad.

Tercero. Destaco, ahora, los enunciados que en su conjugación fecunda programan la armazón del Estado y su sujeción al Derecho de la Constitución. Más allá de la ductilidad cierta o incierta de la "simple declaración" constituyente, corresponde indicar que desde su Preámbulo se anuncia, sin presuntuosidad pero con vocación normativa, lo siguiente:

El Pueblo de Colombia, en ejercicio de su poder soberano, representado por sus delegatarios a la Asamblea Nacional Constituyente, invocando la protección de Dios, y con el fin de fortalecer la unidad de la Nación y asegurar a sus integrantes la vida, la convivencia, el trabajo, la justicia, la igualdad, el conocimiento, la libertad y la paz, dentro de un marco jurídico, democrático y participativo que garantice un orden político, económico y social justo, y comprometido a impulsar la integración de la comunidad latinoamericana, decreta, sanciona y promulga la siguiente Constitución Política de Colombia.

A su vez, las primeras palabras de las prescripciones constitucionales, precisamente en el artículo 1, se dirigen a ordenar:

Colombia es un Estado social de derecho, organizado en forma de República unitaria, descentralizada, con autonomía de sus entidades territoriales, democrática, participativa y pluralista, fundada en el respeto de la dignidad humana, en el trabajo y la solidaridad de las personas que la integran y en la prevalencia del interés general.

Luego, en el artículo 3 se encuentra una determinación jurídica clave: "La soberanía reside exclusivamente en el pueblo, 
del cual emana el poder público. El pueblo la ejerce en forma directa o por medio de sus representantes, en los términos que la Constitución establece". Téngase presente que, más adelante, en el artículo 113, se determina taxativamente que "son ramas del poder público, la legislativa, la ejecutiva y la judicial”.

Los enunciados referidos dan suficiente cuenta de la idea de constituir un Estado, el origen del poder y el criterio para su ejercicio. La sujeción del Estado al Derecho de la Constitución se encuentra de modo indubitable en las referencias alegadas. Todo se corona en el artículo 121: "Ninguna autoridad del Estado podrá ejercer funciones distintas de las que le atribuyen la Constitución y la ley".

El Estado colombiano posee, desde 1991, una de las reglas señeras, quizá la mejor redactada sobre supremacía constitucional. Me refiero al artículo 4:

La Constitución es norma de normas. En todo caso de incompatibilidad entre la Constitución y la ley u otra norma jurídica, se aplicarán las disposiciones constitucionales. Es deber de los nacionales y de los extranjeros en Colombia acatar la Constitución y las leyes, y respetar y obedecer a las autoridades.

Dispuesta la subordinación del Estado al Derecho de la CPC 1991, sólo resta indagar la cuestión del espacio jurídico del DIDH, según menciona el propio instrumento en el artículo 93:

Los tratados y convenios internacionales ratificados por el Congreso, que reconocen los derechos humanos y que prohíben en su limitación en los estados de excepción, prevalecen en el orden interno. Los derechos y deberes consagrados en esta Carta, se interpretarán de conformidad con los tratados internacionales sobre derechos humanos ratificados por Colombia.

La aparición de esta regla positiva en el mundo jurídico constitucional de América del Sud ha provocado, significativamente, nuevos deslizamientos, porque ha cambiado el sistema de fuentes, al referirse propiamente sobre la materia. De manera 
decidida el constituyente se inclinó por el criterio de la prevalencia en el "orden interno" del DIDH. No obstante, en el caso de los "derechos y deberes" consagrados por la propia Constitución colombiana de 1991, configura un patrón de interpretación, dado que ellos deberán ser interpretados "de conformidad" con los tratados internacionales sobre DDHH ratificados por Colombia.

No es objeto de estas líneas hacer una digresión sobre si la CPC 1991 debe ser calzada dentro del marco del ámbito referenciado como Derecho interno o no debe ser enmarcada como tal; esto es, si la prevalencia del DIDH se desenvuelve en todo espacio y tiempo. Sin embargo, nótese que la ordenación constituyente por la fórmula "de conformidad" se encuentra lejos de una mera o simplificada referencia; tal circunstancia anida, cuanto menos, un parámetro para la realización constitucional. La única dificultad tangible para los ciudadanos y servidores públicos podría reposar en que sea necesaria una previa investigación de campo para hallar los "tratados y convenciones" que reconocen el DIHH y que han sido "distinguidos" con su "ratificación" por el Congreso colombiano.

Cuarto. La creación constitucional, ya sea la primera instauración de la Ley fundamental o su reforma, se lleva adelante en los momentos constituyentes. En otras palabras, en los momentos constituyentes, los ciudadanos que integran el pueblo, representados por sus asambleístas o en forma directa por derecho propio, pueden dar lugar al ejercicio del poder que permite la configuración constitucional que da fundamento al Estado. Por eso, se naturaliza y califica a este poder constituyente como "originario" o "derivado" 67 .

Sobre el poder constituyente originario se ha dicho que es aquel que organiza y da asiento jurídico por primera vez a una comunidad $^{68}$. En mi opinión, el poder constituyente originario

67 Bidart Campos, Germán J.: Tratado Elemental de Derecho Constitucional Argentino, t. I, Buenos Aires, Ediar, 1995, p. 188.

68 SротA, Alberto Antonio: Lo político, lo jurídico, el derecho y el poder constituyente, Buenos Aires, Plus Ultra, 1993. 
es aquella fuerza capaz de establecer las bases de la estructura política, económica, cultural y jurídica de una comunidad estatal, en un espacio territorial y un tiempo determinado. El poder constituyente derivado es el que se ejerce para canalizar las preferencias ciudadanas y variar el contenido de la Constitución, merced a su proceso de reforma.

El poder constituyente originario, ejercido en la etapa de la fundación o de organización primigenia del Estado por intermedio de la Constitución, básicamente no tiene límites. La creación jurídico-constitucional queda sometida, con exclusividad, a la deliberación y discusión política que le da nacimiento. Resulta muy difícil adjudicar límites jurídicos al acto constituyente de instauración de la primera Ley fundamental, cuya naturaleza y peso son eminentemente políticos. Desde el punto de vista lógico, la colocación de límites jurídicos al acto constituyente auroral constituye una falacia. No obstante, aunque el Derecho positivo no implica la democracia, esta última sí "implica, necesariamente, al Derecho"69.

En consecuencia, la fundación del Estado constitucional y "democrático" sí se halla limitada por una combinación de reglas que confieren soberanía al individuo singular y autodeterminación colectiva a tales individuos como integrantes de la comunidad, por las que se los tutela y dignifica a todos en cuanto personas y se iguala la participación política de todos en cuanto ciudadanos. También debería añadirse la conglobación emanada del constitucionalismo global, fruto de los instrumentos internacionales sobre derechos humanos, creados a partir de las lecciones de la historia en el siglo xx. En su Ética nicomaquea, Aristóteles sostuvo que el "cambio perpetuo" de las leyes humanas era una opinión "verdadera en parte"70; dicha variación dialéctica del capital jurídico, en el siglo xxı, tiene una contención, la que se anima en las esperanzas depositadas en

69 FenRajolı, Luigi: Principia iuris. Teoría del Derecho y de la democracia, t. 2: "Teoría de la democracia", ob. cit., p. 17.

70 Aristóteles: Ética nicomaquea, Buenos Aires, Losada, 2007, p. 186. 
principios de Derecho internacional que ilustran la emancipación universal de los seres humanos.

En cambio, cuando se lo ejerce para reformar o variar la regla jurídica básica del Estado, se está en presencia del poder constituyente derivado. En los momentos constituyentes en que se ejerce el poder constituyente derivado, existen límites formales o, eventualmente, materiales. Los límites formales determinan a qué sujeto calificado compete y a qué procedimiento específico debe atenerse la realización de la creación constitucional reformadora. Así, los límites del mundo constitucionalmente posible de la propia CPC 1991 son puestos por su propio lenguaje prescriptivo.

También se determinan límites materiales al cambio constitucional. Estos topes definen obstáculos a la reforma. En pocas palabras, plantean o disponen la invariabilidad de determinado fragmento de la materia constitucional. Tales prohibiciones pretenden impedir que una reforma recaiga sobre determinado contenido constitucional. Se comprenderá la importancia que asume la cuestión sobre los límites materiales al poder de reforma, peculiarmente, en aquellas Constituciones que contemplan que pueden reformarse "en el todo", o que sin decirlo lo habilitan implícitamente, o no prohíben la variación en cualquiera de sus partes. La Constitución colombiana puede reformarse en el todo (referendo o por Asamblea Nacional Constituyente), o al menos ello no se encuentra prohibido, aunque de esta afirmación no se deriva que no existan límites materiales o reglas de intangibilidad.

Quinto. Desde su Preámbulo, la Ley fundamental colombiana anuncia que "El pueblo de Colombia, en ejercicio de su poder soberano, representado por sus delegatarios a la Asamblea Nacional Constituyente [...] decreta, sanciona y promulga la siguiente Constitución Política de Colombia”. Para desarrollar ese postulado, en el artículo 3 se determina que el pueblo ejerce el poder soberano en "forma directa" o por "medio de sus representantes" y dentro de los patrones ordenados en la propia Ley fundamental. 
Muchas Constituciones formulan, por regla normativa, que el poder emana del pueblo. Por lo demás, se trata de un feliz acontecimiento, porque la regla constitucional se separa de la errónea doctrina normada en el artículo 2 de la Constitución de 1886, en tanto se disponía que "La soberanía reside esencial y exclusivamente en la Nación, y de ella emanan los poderes públicos, que se ejercerán en los términos que esta Constitución establece”.

El término "nación" tiene carta de ciudadanía en el discurso político institucionalizado en documentos jurídicos a partir de la Revolución francesa de 1789. De allí en adelante impregnó el discurso de las fuentes dogmáticas y luego de las normativas. "Nación" correspondería ser entendida, por ejemplo, como un grupo o asociación de hombres unidos por un lazo natural, consecuentemente eterno. La "nación", captada como grupo, asociación o comunidad -típica forma de sociabilidad natural o espontánea-, no es persona jurídica ni sujeto de derechos; ergo, no puede convertirse u ordenarse como Estado. De acuerdo con la tesis primitiva alentada en esta disertación, el fundamento de todo es el ciudadano, concretamente la unión mancomunada de todos ellos y que da lugar al elemento natural del Estado; mal grado, pues, podría residir en una "nación", que carece de la reunión libre de las individualidades atomísticas, la fuente misma de todo el poder político.

La CPC 1991, según se dispone en el artículo 374, instituye tres procesos singulares para reformar la Ley fundamental: por el Congreso, por una Asamblea Constituyente o por el pueblo mediante referendo.

En primer lugar, me refiero al Congreso. La tarea legislativa es básica en la actuación congresual. Al respecto, hay una disposición curiosa en la CPC 1991, el artículo 150, inciso 1. Allí se dispone, en cuanto aquí concierne, que "Corresponde al Congreso hacer las leyes. Por medio de ellas ejerce las siguientes funciones. 1. Interpretar, reformar y derogar las leyes". Si a ello se suma, como se examina a partir del párrafo que sigue abajo, que el Congreso puede emitir "actos legislativos" reformatorios de la Ley fundamental, inquieta conocer el alcance de lo normado 
en el artículo 150, inciso 1. Así, a poco que se examine que los Congresos, en la abstracción propia de la teoría constitucional y en la base empírica sugerida por el Derecho constitucional comparado, son el teatro de la deliberación democrática y el órgano para desarrollar una Constitución, no hay que lidiar con el artículo 150, inciso 1 . Intuyo que se trata de un pleonasmo jurídico, dado que para legislar, ya sea en versión ordinaria o extraordinaria, siempre, el ser humano, con naturaleza previa ha de conocer. Según mi comprensión, el verbo "interpretar" adquiere vitalidad a condición de que su ámbito semántico se refiera al hecho de que el Congreso declara para sí mismo -es decir, para sus integrantes- el propio "sentido del orden jurídico", antes de reformar o derogar.

En el orden jurídico colombiano también el Congreso puede asumir el poder constituyente derivado. Cuando el Congreso de Colombia concreta una reforma constitucional, lo hace bajo la forma de un "acto legislativo". Todas las reformas que se han realizado desde 1991 han sido calzadas dentro de este escenario constituyente, excepto la referida a "pérdida de derechos políticos" (2004), que fue "decretada" por "el pueblo de Colombia", dentro del régimen establecido para el "referendo constitucional".

En el artículo 375 se instituye que pueden articular proyectos de "acto legislativo" sobre reforma constitucional (AL) los siguientes actores sociales: “... el Gobierno ${ }^{71}$, diez miembros del Congreso, el veinte por ciento de los concejales o de los

71 CPC 1991, art. 115: “El Presidente de la República es Jefe del Estado, Jefe del Gobierno y suprema autoridad administrativa.

"El Gobierno Nacional está formado por el Presidente de la República, los ministros del despacho y los directores de departamentos administrativos. El Presidente y el Ministro o Director de Departamento correspondientes, en cada negocio particular, constituyen el Gobierno.

"Ningún acto del Presidente, excepto el de nombramiento y remoción de Ministros y Directores de Departamentos Administrativos y aquellos expedidos en su calidad de Jefe del Estado y de suprema autoridad administrativa, tendrá valor ni fuerza alguna mientras no sea suscrito y comunicado por el Ministro del ramo respectivo o por el Director del Departamento Administrativo correspondiente, quienes, por el mismo hecho, se hacen responsables". 
diputados $^{72}$ y los ciudadanos en un número equivalente al menos, al cinco por ciento del censo electoral vigente". En el artículo 237, inciso 4, también se atribuye legitimación al Consejo de Estado para "preparar y presentar proyectos de actos reformatorios de la Constitución". Asimismo, el Consejo Nacional Electoral tiene atribuciones para presentar "proyectos de acto legislativo" (art. 265, inc. 5).

El trámite del proyecto de acto legislativo se realizará en dos períodos congresuales ordinarios y consecutivos; el primero se extiende desde el 20 de julio hasta el 16 de diciembre, y el segundo, desde el 16 marzo hasta el 20 de junio. Aprobado en la primera vuelta, "por la mayoría de los asistentes" tanto de la Cámara de los Representantes como del Senado, el proyecto será publicado por el Gobierno. La publicación en el Diario Oficial aumentaría las posibilidades de conocimiento y discusión del proyecto en el auditorio comunitario.

Particularmente, la participación ciudadana, tesis primitiva anunciada en este escrito, encuentra en el artículo 375 constitucional un corolario bien dispuesto; no obstante, más allá de la precisión semántica de la norma que habilitaría el debate en el ágora, la mera publicación del proyecto de AL no conduce por sí misma a la prospección y al escrutinio riguroso de su textura. En paralelo, la costumbre demuestra que el Gobierno aprovecha el escenario para confiar un análisis y valoración del proyecto de $\mathrm{AL}$, ya sea para impulsarlo o impedirlo, texto que resulta enviado al Congreso. Luego de su "publicación" y para conseguir su aprobación, el acto legislativo requerirá una segunda vuelta de aprobación congresual; en este caso, se exigirá el apoyo de "la mayoría de los miembros de cada Cámara".

Sin embargo, hay determinados "actos legislativos" cuya variación, por imperativo constitucional, queda también sometida

\footnotetext{
72 En el art. 155 de la CPC 1991 se establece que podrán presentar proyectos de reforma constitucional el treinta por ciento de los concejales o diputados del país. A mi juicio, en el ámbito de la antinomia descrita, debería prevalecer la legitimación estipulada en la regla especial, esto es, la dispuesta en el art. 375.
} 
a referendo. En efecto, según lo ordenado por el artículo 377, deberán someterse a referendo las reformas constitucionales aprobadas por el Congreso, cuando se refieran a los derechos reconocidos en el Capítulo 1 (De los derechos fundamentales) del Título II, y a sus garantías, a los procedimientos de participación popular, o al Congreso, si así lo solicita, dentro de los seis meses siguientes a la promulgación del Acto Legislativo, un cinco por ciento de los ciudadanos que integren el censo electoral. Finalmente, en la misma norma se añade que la reforma quedará derogada por el voto negativo de la mayoría de los votantes, siempre que en la elección popular hubiere participado al menos la cuarta parte del censo electoral.

En segundo lugar, en cuanto a la Asamblea Constituyente, la iniciativa para su convocatoria reside con exclusividad en el Congreso. No hay otro sujeto constitucionalmente legitimado para impulsarla. En el artículo 376 de la CPC 1991 se dispone que por intermedio de “... una ley aprobada por mayoría de los miembros de una y otra Cámara, el Congreso podrá disponer que el pueblo en votación popular decida si convoca una Asamblea Constituyente con la competencia, el período y la composición que la misma ley determine".

No existe un manual del usuario para disponer reglas sobre las reformas constitucionales. La reforma es un fragmento de cualquier Constitución y se une a los otros tres fragmentos que completan el todo del mapa teórico: las simples declaraciones; los derechos, bienes y deberes fundamentales y la distinción de funciones junto con el control del poder. Por lo general, las reglas sobre la reforma tienen una presentación literaria conjunta en la textura constitucional para evitar dispersiones, las que, a su vez, serían susceptibles de generar alguna distorsión interpretativa, mayor o menor, salvable o no salvable.

En el caso de la Asamblea Constituyente colombiana, para completar su itinerario hay que pasar del Título xIII ("De la reforma de la Constitución") al Título viII ("Rama Judicial". Capítulo 4. "De la jurisdicción constitucional"). Aprobado el proyecto por el Congreso, tal como se describe en el párrafo 
anterior, el pueblo no intervendrá de inmediato. Según se ordena en el artículo 241, inciso 2, jugará un papel extraordinario la CCC, órgano al que se atribuye competencia para "Decidir, con anterioridad al pronunciamiento popular, sobre la constitucionalidad de la convocatoria [...] a una Asamblea Constituyente para reformar la Constitución, sólo por vicios de procedimiento en su formación”. Así, una vez sancionada la ley que convoca la consulta, el Presidente de la República la remitirá a la Corte Constitucional para que ésta decida previamente sobre su constitucionalidad formal.

Finiquitado el trámite en la CCC, la convocatoria a la Asamblea Constituyente la realizará el pueblo, si así lo aprueba, cuanto menos, una tercera parte de los integrantes del censo electoral (art. 376, ap. segundo). Naturalmente, el pueblo, aquí, determinará la agenda jurídica de debate "en" y "de" la Asamblea Constituyente, dado que no es razonable ni justificable aguardar su cambio por los propios asambleístas, que fijasen cualquier contenido deseado por ellos, en el momento constituyente propio que se constituya el órgano reformador. Si bien la reforma constitucional puede ser total, en este caso, la "competencia" para variar totalmente la CPC 1991 tiene que ser determinada de antemano en la propia convocatoria congresual.

Además de la propia aprobación del Congreso, deberá gozar del beneplácito del control previo de constitucionalidad y la anuencia del cuerpo electoral en los porcentajes exigidos por la Ley fundamental. La Asamblea Constituyente no debería reformar la CPC 1991 si no se siguiese el protocolo indicado; todo ello, sin perjuicio, de los contenidos que se juzguen irreformables, tal como describo más arriba, en el parágrafo Cuarto de esta misma subsección y también más abajo, en la subsección IV.C.

Los representantes del pueblo que integrarán la Asamblea Constituyente deberán ser elegidos por el "voto directo de los ciudadanos, en acto electoral que no podrá coincidir con otro" (art. 376, tercer ap.). Respecto de la integración de la Asamblea Constituyente, la CPC 1991 no ha contemplado el sistema 
electoral aplicable. Además, legalmente se ha dispuesto que “... la consulta para convocar una Asamblea Constituyente y la elección de sus delegatarios serán dos actos separados"; esta última deberá realizarse entre los dos y los seis meses a partir de la fecha de la expedición de la ley. Las dos votaciones no podrán coincidir con otro acto electoral (art. 63, Ley 134 [de 1994]).

Por su parte, en el artículo 376 se prescribe que "A partir de la elección quedará en suspenso la facultad ordinaria del Congreso para reformar la Constitución durante el término señalado para que la Asamblea adelante sus funciones".

Por último, en cuanto al referendo ciudadano, en la escritura de la CPC 1991 se descubre la "participación democrática y de los partidos políticos". Para tales fines se dispone todo el Título Iv de la Ley fundamental, independientemente de la conjugación de otras normas que se refieren a la materia y que también penetran en su textura.

El Título Iv se divide en los siguientes capítulos: 1 ("De las formas de participación democrática"); 2 ("De los partidos y de los movimientos políticos"); 3 ("Del Estatuto de la oposición"). Las normas allí planteadas forman un clarísimo gesto colectivo del poder constituyente originario, cuyas figuras y colores participativos se irradian hacia la comprensión global de la "presentación literaria"73 de la Ley fundamental colombiana de 1991. Al respecto, resulta ilustrativo el texto contenido en el artículo 103: "Son mecanismos de participación del pueblo en

\footnotetext{
73 Con motivo del $20^{\circ}$ aniversario de la CPC 1991, se ha narrado la intervención de Gabriel García Márquez en "la elaboración de la propuesta constitucional del Gobierno". Humberto de la Calle, a la sazón representante del Gobierno ante la Asamblea Constituyente, ha dicho que por pedido del Premio Nobel de Literatura de 1982, “... le enviábamos copias de los borradores del proyecto del gobierno. No sólo se interesó en la redacción, sino que expuso sus juicios en notas manuscritas al pie del los documentos. Al ver la propuesta de Preámbulo y enfrentar la discusión sobre la mención de Dios [...], García Márquez propuso que se dijera que la Constitución se expedía 'en nombre de todos los Dioses de Colombia'. Esta iniciativa fue recogida por los grupos indígenas". V. De la Calle, Humberto, "La pluma de García Márquez en la Constitución", El Espectador, Bogotá, 3/7/2011, disponible en https:// www.elespectador.com/content/la-pluma-de-garc\%C3\%ADa-m\%C3\%A1rquez-en-laconstituci\%C3\%B3n, consultado por última vez el 25/5/2018.
} 
ejercicio de su soberanía: el voto, el plebiscito, el referendo, la consulta popular, el cabildo abierto, la iniciativa legislativa y la revocatoria del mandato. La ley los reglamentará".

En cuanto concierne estrictamente con esta escritura, el referendo es un magnífico instrumento de participación ciudadana. Una o varias normas jurídicas son sometidas al escrutinio ciudadano, cuyo juicio de aprobación o rechazo culmina el proceso de producción normativa: la palabra final de cada uno de los ciudadanos que integran el pueblo. La infinitesimal alícuota que cada ciudadano posee, por la envergadura misma de su emplazamiento como tal, adquiere un vigor inusitado en la participación democrática del referendo. La producción jurídica comienza, descansa y termina en la decisión de cada ciudadano, cuando transita la significancia del referendo.

El referendo no hace que un Estado constitucional sea más o menos democrático; definitivamente, la espesura de la institución puede medir la propia extensión de la forma democrática del ente. El referendo es como una puesta de sol, inconfundible por sus cualidades físicas y por su energía cívica. Líneas más arriba he insinuado con firmeza que la ciudadanía tiene voz propia pero no única, porque, precisamente, el conjunto de esas voces configura la arquitectura misma del pluralismo.

De conformidad a los artículos 155 y 378 de la CPC 1991, se instituye que disponen de iniciativa para proponer una reforma de la Ley fundamental, por la vía del referendo, un grupo de ciudadanos igual o superior al cinco por ciento del censo electoral existente en la fecha respectiva, o el gobierno.

A su turno, le corresponderá decidir al Congreso respecto de la iniciativa de referendo presentada por ciudadanos o por el Gobierno. En el apartado final del artículo 155 se ordena que "Los ciudadanos proponentes tendrán derecho a designar un vocero que será oído por las Cámaras en todas las etapas del trámite".

Para que prospere el sometimiento del proyecto de reforma constitucional a referendo, será necesaria "la aprobación de la 
mayoría de los miembros de ambas Cámaras" (art. 378). Si el Congreso decidiese avanzar con el referendo sobre un proyecto de reforma constitucional, deberá incorporarlo a la ley de convocatoria y será “... presentado de manera que los electores puedan escoger libremente en el temario o articulado qué votan positivamente y qué votan negativamente" (art. 378).

Repárese en el siguiente detalle constitucional. Una vez sancionada la ley que convoca al referendo sobre un proyecto de reforma constitucional, antes del pronunciamiento ciudadano, corresponderá, aquí también, la intervención de la CCC sobre la constitucionalidad de la convocatoria, aunque sólo sobre vicios en el procedimiento (art. 241, inc. 2). Será el presidente de la República, en este caso, el servidor público encargado de remitir el proyecto de reforma por la vía del referendo a la CCC.

Culminada la intervención del poder constituido CCC sobre un acto típico del poder constituyente derivado, en este caso, el proyecto de reforma constitucional requerirá “... el voto afirmativo de más de la mitad de los sufragantes, y que el número de éstos exceda de la cuarta parte del total de ciudadanos que integren el censo electoral", según se exige en la última parte del artículo 378.

Para finalizar, no hay recetas que otorguen bases de certidumbre para distinguir la robustez o debilidad del constitucionalismo. El hecho concreto de que dos o tres Constituciones contemplen, con lenguaje "semejante", una determinada institución, no implica el desarrollo "semejante" de las Leyes fundamentales. Cada texto constitucional -el abanico de su articulado finito- se enmarca siempre en el contexto cultural $^{74}$ que lo arropa. Ningún texto posee un carácter ilimitado, porque su realización siempre deberá, forzosamente, detenerse en los alcances racionales que orientan su sentido. El sinsentido, la irracionalidad, no es una tarea computable para el saber o dogmática constitucional. Por todo ello, la participación ciudadana,

74 HÄBERLE, Peter: "La Constitución en el contexto", ob. cit., p. 228. 
en este caso por la vía del referendo, constituye una instancia capaz de dividir, acaso, los modelos constitucionales de América del Sud.

Así, como se lee en las letras escritas más arriba, hay modelos, como el colombiano, que lo contiene, aunque lo conduce, por momentos, sobre arenas movedizas. También existen otros, como el de la orden constitucional de la Argentina, que no lo contempla, y hasta alguna dogmática autoral sostendría que se encuentra prohibido constitucionalmente. Dada entonces la importancia decisiva que se atribuye en este escrito a la participación más robusta de la ciudadanía, ha llegado el momento de repetir que "nada está perdido si se tiene por fin el valor de proclamar que todo está perdido y que hay que empezar de nuevo" 75 . Obviamente, me refiero, por un lado, a los modelos constitucionales que desautorizan la inclusión del ciudadano en el proceso de variación constitucional y, por otro, a aquellos que lo autorizan, pero que merecerían ser perfeccionados.

\section{IV.C. Interludio. La doctrina de la sustitución en el ámbito de la Constitución de 1991}

La CCC tiene un rol importante dentro de los procesos de reforma constitucional. Una participación distintiva, dueña de un protagonismo bastante inusual, en la comparación de los modelos constitucionales de América del Sud. Más arriba ya he insinuando su papel institucional respectivo.

Se ha visto, pues, que el órgano CCC posee competencia para intervenir con control "previo", automático y oficioso de los actos reformatorios. Recuérdese que ello sucede tanto en las leyes de convocatoria a referendo reformatorio de la CPC 1991 (arts. 241, inc. 2, y 378) como sobre las leyes de convocatoria a una Asamblea Constituyente (arts. 241, inc. 2, y 376).

Por su parte, en el artículo 241, inciso 1, se define un control de constitucionalidad a posteriori:

75 Cortázar, Julio: Rayuela, Buenos Aires, Alfaguara, 2004, p. 408. 
Artículo 241. A la Corte Constitucional se le confía la guarda de la integridad y supremacía de la Constitución, en los estrictos y precisos términos de este artículo. Con tal fin, cumplirá las siguientes funciones:

1. Decidir sobre las demandas de inconstitucionalidad que promuevan los ciudadanos contra los actos reformatorios de la Constitución, cualquiera que sea su origen, sólo por vicios de procedimiento en su formación.

Además, en el artículo 379 se instituye:

Artículo 379. Los Actos Legislativos, la convocatoria a referendo, la consulta popular o el acto de convocación de la Asamblea Constituyente, sólo podrán ser declarados inconstitucionales cuando se violen los requisitos establecidos en este título.

La acción pública contra estos actos sólo procederá dentro del año siguiente a su promulgación, con observancia de lo dispuesto en el artículo 241 numeral 2.

En los artículos 243 y 244 , respectivamente, se determinan los efectos de la sentencia de la CCC:

Artículo 243. Los fallos que la Corte dicte en ejercicio del control jurisdiccional hacen tránsito a cosa juzgada constitucional.

Ninguna autoridad podrá reproducir el contenido material del acto jurídico declarado inexequible por razones de fondo, mientras subsistan en la Carta las disposiciones que sirvieron para hacer la confrontación entre la norma ordinaria y la Constitución.

Artículo 244. La Corte Constitucional comunicará al Presidente de la República o al Presidente del Congreso, según el caso, la iniciación de cualquier proceso que tenga por objeto el examen de constitucionalidad de normas dictadas por ellos. Esta comunicación no dilatará los términos del proceso.

La conformidad con la Constitución, en sentido estricto, es decir, constitucionalidad de una reforma, resulta predicable cuando se respetan la forma y los contenidos autorizados por 
la propia Ley fundamental, tal como anuncié en la subsección IV.A.bis. Esta conformidad, pues, no es otra cosa que correspondencia: que se satisfagan las condiciones de una relación. La validez de una reforma constitucional es la relación de conformidad entre las disposiciones creadas y las disposiciones que regulan su producción. Por lo tanto, validez de una reforma constitucional es un concepto relacional que designa, fundamentalmente, la relación de pertenencia de un nuevo enunciado con la Constitución, siempre que se hayan observado todas las etapas que regulan y disciplinan su creación normativa.

Por su parte, el significado de la inconstitucionalidad incluye, en el análisis, la idea de disconformidad, no de conformidad. La inconstitucionalidad es un vicio o defecto que, si bien se circunscribe habitualmente al enfrentamiento entre disposiciones infraconstitucionales con la Ley Mayor, puede producirse a nivel de la Constitución misma, cuando por medio de una reforma se violenta el principio de unidad del sistema, configurado principalmente por los lindes prefijados para el desarrollo de una enmienda. Una reforma inconstitucional es la expresión más grave de una patología de la Constitución.

Según la intensidad y la extensión del factor de perturbación, la patología puede acarrear desde una instancia revolucionaria, es decir, el reemplazo de la Constitución por una de pretensiones francamente contradictorias (con fundamento de validez en una regla de reconocimiento antidemocrática), hasta los casos de fisura del sistema. En estos supuestos, en cuanto a ciertos asuntos relacionadas con el proceso de reforma, y únicamente respecto de ellos, existe una diferencia dentro del mundo oficial que conduce a una división en el ámbito de los poderes públicos respecto del criterio para identificar a la Constitución reformada ${ }^{76}$. Convendrá admitir que la inconstitucionalidad de una reforma puede asumir dos formas: una débil, aparentemente remediable; y una fuerte, seguramente irremediable. Tal distinción es consecuencia, a su vez, de esa otra distinción que

76 Cfr. HaRt, H. L. A.: El concepto de Derecho, Buenos Aires, Abeledo Perrot, 1992, pp. 146-151. 
la dogmática jurídica suele establecer entre validez formal y validez material ${ }^{77}$.

Se podrá predicar que una reforma constitucional es inválida formalmente si no se observó la regularidad de las reglas que ordenan el proceso de reforma. Toda reforma que infrinja o ponga en tela de juicio o de sospecha el cumplimiento estricto de los límites formales podrá ser atacada por portar esta patología: inconstitucionalidad, por haberse infringido tales limitaciones.

En contraste, se predicará que es inválido por razones materiales un cambio que afecte una materia considerada intangible por la Constitución, de imposible modificación por infringir una limitación material. Difícilmente en estos casos la invalidez material pueda ser reconocida, porque se habría abolido la Constitución anterior; se trataría, en rigor, de una invalidez total e irreversiblemente irremediable. ${ }^{78}$

En líneas anteriores (subsección IV.A.bis) he descripto las reglas pétreas que puede contener una Ley fundamental. Paralelamente, se infieren las dudas que dicho material normativo irreformable podría generar. Además, sin sutilezas, me atrevo a pensar y justificar las razones por las cuales la "democracia" (forma política de orientación del Estado) -el método-y la "república"79 (forma jurídica que asume el gobierno

\footnotetext{
77 V. Guastinı, Riccardo: Estudios de teoría constitucional, México, Fontamara, 2001, p. 92.

78 El constitucionalista Pablo Riberi expresa que “... no es posible que las premisas políticas, deliberativas, popularmente igualitarias del autogobierno en la instancia constituyente puedan verse derogadas por las conclusiones epistémico-sustantivas invalidantes que quieran imponer jueces y académicos". En cambio, a su juicio, los "límites democráticos-procedimentales" pueden tener asidero. V. Riberi, Pablo: "Límites sobre el poder constituyente: subjetividades y agonías del criptoconstitucionalismo", en AA.VV., Nuevas perspectivas en Derecho Público, Santiago de Chile, Librotecnia, 2011, p. 146.

79 La Constitución de la República de Italia de 1947 prevé en su art. 139: "La forma republicana no puede ser objeto de revisión". ¡Una verdadera maravilla de la formulación escrita de la lengua del Derecho constitucional! La dogmática dominante aprecia en la regla un límite material absoluto, insuperable. La Corte Constitucional, en la sentencia 1.146 decidida en Roma, el 15/12/1988, definió que la Constitución italiana contiene algunos principios supremos que no pueden ser subvertidos o modificados en su contenido esencial, ni siquiera por leyes de revisión constitucional o por otras leyes constitucionales. Tales son tanto los
} 
constitucional) -su casa- son las implicaciones más directas de un repaso de la colección de piezas de los diferentes modelos del constitucionalismo en vigor en América del Sud. Asimismo, se distinguen -dentro de una concepción netamente teórica- las etapas del proceso de reforma constitucional y, en su ámbito, los supuestos que darían lugar a una inconstitucionalidad formal y a una inconstitucionalidad material.

Dentro de las Constituciones de los Estados de América del Sud, la Constitución de Brasil de 1988 contiene, probablemente, la pieza sobre intangibilidad más elocuente, sincera y robusta. Así, en el artículo 60, regla que se ha mantenido inalterada desde 1988, por obra del poder constituyente originario brasileño, se dispone lo siguiente:

A Constituição poderá ser emendada mediante proposta:

I - de um terço, no mínimo, dos membros da Câmara dos Deputados ou do Senado Federal;

II - do Presidente da República;

III - de mais da metade das Assembléias Legislativas das unidades da Federação, manifestando-se, cada uma delas, pela maioria relativa de seus membros.

$\S 1^{\circ}$ A Constituição não poderá ser emendada na vigência de intervenção federal, de estado de defesa ou de estado $\$ e^{2}$ sítoproposta será discutida e votada em cada Casa do Congresso Nacional, em dois turnos, considerando-se

principios que la misma Constitución explícitamente prevé como límites materiales absolutos al poder de revisión constitucional, como la forma republicana (art. 139), como los principios que, por no estar expresamente mencionados entre aquellos no factibles de ser sometidos al procedimiento de revisión constitucional, pertenecen a la esencia de los valores supremos sobre los cuales se funda la Constitución italiana. Gustavo Zagrebelsky interpreta que la naturaleza irreformable del art. 139 de la Constitución de Italia significa igual prohibición de variación del principio democrático escrito en el art. 1: "Italia es una república democrática". Entiende que estos dos artículos condensan principios irrenunciables, razón por la cual, con independencia de la lectura del art. 139, el principio democrático es un principio supremo, de rango superior a las demás reglas constitucionales. Ambos constituyen el núcleo esencial e inmodificable de la Constitución. V. Zagrebelsky, Gustavo: Manuale di Diritto Costituzionale, II sistema delle fonti del Diritto, Volume primo, ristampa, Torino, Utet, 2000, pp. 102-130. 
aprovada se obtiver, em ambos, três quintos dos votos dos respectivos membros.

$\S 3^{\circ} \mathrm{A}$ emenda à Constituição será promulgada pelas Mesas da Câmara dos Deputados e do Senado Federal, com o respectivo número de ordem.

$\S 4^{\circ}$ Não será objeto de deliberação a proposta de emenda tendente a abolir:

I - a forma federativa de Estado;

II - o voto direto, secreto, universal e periódico;

III - a separação dos Poderes;

IV - os direitos e garantias individuais.

Ni la Constitución federal de la Argentina ni la Constitución colombiana de 1991 son portadoras, en el marco de referencia de sus lenguas prescriptivas, de un caudal normativo como el brasileño. Repito: esta circunstancia no habilita a predicar la inexistencia de límites materiales a los actos reformatorios; el problema que se presenta, ante la formulación expresa de sus normas, consiste en quiénes, cómo y con qué contenido han de dibujar la naturaleza implícita de tales límites, en caso de que existiesen...

Por lo pronto, la definición de límites materiales implícitos sobre un texto constitucional se revela como una tarea de ciudadanos y servidores públicos. Esperé hasta aquí para sostener que un escritor que no es ciudadano ni servidor público puede guiarse, simplemente, por intuiciones teóricas que se asomarían a un criterio dogmático. No más que eso.

No será una sorpresa para el lector, ahora, que la democracia y la república, respectivamente, con el sentido elaborado en este texto, puedan ser entendidas como límites materiales implícitos en la CPC 1991 y, por tanto, fuera del alcance del poder reformador constituyente. Sin embargo, cometería un pecado capital si acaso no involucrara, también, a los derechos y bienes fundamentales. La CPC 1991 ha adjudicado verdaderas líneas de acción para el ejercicio de la fuerza y las existencias comunitarias, en su solvente y sabroso desarrollo de los 
derechos y bienes fundamentales. Éstos son verdaderos postes objetivados, que operan como límites y vínculos indisponibles para el poder reformador en la Ley fundamental colombiana, que ninguna mayoría podría desnaturalizar, si se pretende mantener la secuencia de validez jurídica de la CPC 1991.

La CPC 1991 estableció el control de constitucionalidad a cargo de la CCC contra los actos reformatorios de la Ley fundamental, sólo por "vicios de procedimiento en su formación", de oficio o a petición de parte, según el caso (cfr. art. 241, incs. 1 y 2).

En la línea jurisprudencial abierta hasta el 2003, la CCC entendió que el control de las reformas constitucionales que realiza el Congreso de la República únicamente comprende los aspectos formales, de conformidad con el artículo 241, numeral 2, de la CPC 1991: "sólo vicios de procedimiento en su formación". Mantuvo este criterio en sentencias como la C-753, de 1994; la C-222 y la C-387, de 1997; la C-543, de 1998, y la C-487, de 2002. Por eso, en el período señalado, la Corte Constitucional colombiana mantuvo una interpretación literal y sistemática de la Constitución en cuanto a la reforma por medio de actos legislativos, según la cual su facultad de control constitucional únicamente comprendía la verificación del procedimiento seguido por el Congreso al aprobar la reforma. ${ }^{80}$

La CCC modificó su criterio en 2003. En la sentencia C-551 de 2003 plantó la tesis de los vicios de competencia como vicios de procedimiento. Así inaugura, en la sede de la jurisdicción de la Ley fundamental de 1991, la "doctrina jurisdiccional de la sustitución constitucional". La tesis de los vicios de competencia, en teoría, da lugar a dos tipos de juicios.

El primer juicio es a favor de su procedencia jurídico-constitucional. Así, la "competencia" queda involucrada dentro de la idea

\footnotetext{
80 V. Cajas SarRia, Mario Alberto: “¿Límites a la democracia? El control judicial de las reformas constitucionales", ponencia presentada en el Coloquio Internacional sobre "Temas de Derecho Constitucional contemporáneo", organizado por el Instituto de Investigaciones Jurídicas de la Facultad de Derecho de la Universidad Veracruzana, 29/5/2006 al 2/6/2006, Xalapa, México.
} 
de la formación del proceso reformador. No es un razonamiento complejo, porque cuando se dice "competencia", en rigor, se alude a la comprensión de las materias habilitadas en el marco de referencia del "procedimiento". No es un criterio fácil de zanjar. En verdad, la competencia del órgano que produce la norma queda envuelva en el procedimiento de formación; sin embargo, cuando se presentan estas cuestiones no son simples, porque, por lo general, la alusión de "vicio en la competencia" estaría apuntando a contenidos intangibles. En otras palabras, la competencia sería un "elemento" o "presupuesto" del procedimiento reformador, pieza argumental que conduce a la conclusión de que un proceso reformador se hallaría viciado si el órgano que produjo el acto carece de habilitación jurídica, circunstancia que dispondría la justificación del conocimiento de revisión por la CCC.

Quizá uno de los criterios básicos, por cierto, luzca en el fundamento 39 de la sentencia C-551:

... aunque la Constitución de 1991 no establece expresamente ninguna cláusula pétrea o inmodificable, esto no significa que el poder de reforma no tenga límites. El poder de reforma, por ser un poder constituido, tiene límites materiales, pues la facultad de reformar la Constitución no contiene la posibilidad de derogarla, subvertirla o sustituirla en su integridad. Para saber si el poder de reforma, incluido el caso del referendo, incurrió en un vicio de competencia, el juez constitucional debe analizar si la Carta fue o no sustituida por otra, para lo cual es necesario tener en cuenta los principios y valores que la Constitución contiene, y aquellos que surgen del bloque de constitucionalidad, no para revisar el contenido mismo de la reforma comparando un artículo del texto reformatorio con una regla, norma o principio constitucional -lo cual equivaldría a ejercer un control

81 Ramírez Cleves, Gonzalo A.: Límites de la reforma constitucional en Colombia. El concepto de constitución como fundamento de la restricción, Bogotá, Universidad Externado de Colombia, 2009, p. 487. 
material. Por ejemplo, no podría utilizarse el poder de reforma para sustituir el Estado social y democrático de derecho con forma republicana ( $\mathrm{CP}$ art. $1^{\circ}$ ) por un Estado totalitario, por una dictadura o por una monarquía, pues ello implicaría que la Constitución de 1991 fue remplazada por otra diferente, aunque formalmente se haya recurrido al poder de reforma. ${ }^{82}$

Vale señalar que en la sentencia C-551 de 2003 la CCC no determina cuáles han de ser esos límites que, transgredidos o vulnerados, "convertirían a la reforma en una sustitución de la Constitución" 83 ; el órgano acude a referencias genéricas, nunca casuísticas o puntuales, de lo que configuraría una "sustitución" de la Ley fundamental.

Un año más tarde, la CCC, en el rubro 5 de sus "Consideraciones y fundamentos" de la sentencia C 970-2004, determinó lo siguiente: "Se presenta un vicio de extralimitación en la competencia del poder de reforma constitucional por sustitución de la Constitución, cuando mediante el procedimiento especialmente dificultado de reforma se reemplaza totalmente un elemento definitorio identificador de la Constitución" ${ }^{84}$.

A su turno, en la sentencia C-1040 del 2005, se dijo que para determinar el alcance de la doctrina, el juez constitucional debía realizar, al menos dos tareas específicas: "Primero, es necesario establecer cuáles son los elementos esenciales que definen la identidad de la Constitución; y, segundo, cómo puede una reforma llegar a ser realmente una sustitución de la Constitución" ${ }^{85}$.

82 V. Sentencia C-551 (9/7/2003), disponible en http://www.corteconstitucional.gov.co/ relatoria/2003/C-551-03.htm, consultado por última vez el 25/5/2018.

83 Cajas Sarría, Mario Alberto: El control judicial a la reforma constitucional. Colombia 19102007, Cali, Universidad ICESI, 2008, p. 107.

84 Sentencia C-970 (7/10/2004), disponible en http://www.corteconstitucional.gov.co/ relatoria/2004/c-970-04.htm, consultado por última vez el 25/5/2018.

85 Sentencia C-1040 (19/10/2005), disponible en http://www.corteconstitucional.gov.co/ relatoria/2005/C-1040-05.htm, consultado por última vez el 25/5/2018. 
El segundo juicio es en contra de esta doctrina jurisdiccional de la sustitución. Porque la idea o la plantación del argumento sobre "los vicios de competencia" implica un razonamiento constituyente vedado por la CPC 1991. O que configura, en la práctica, una maniobra voluntarista prohibida por ser ajena a la potestad jurisdiccional. En ambos casos, se achaca a la CCC el hecho de que la designación de un control material de la reforma de naturaleza implícita en el texto de la CPC 1991 no fue instaurado por el poder constituyente. Así, pues, la CCC, en un verdadero modelo autorreferente, decidiría la tipicidad del vicio (encubierto bajo el solaz de la "competencia") y se asignaría a sí misma la adjudicación del remedio, con su conocimiento y eventual declaración de inexequibilidad.

La doctrina de la sustitución de la Constitución ha sido confiadamente realizada desde 2003 hasta el presente por los jueces de la CCC. Más arriba se hace conocer el debut de la doctrina en el 2003 y dentro del marco de la CPC 1991. Además de las sentencias citadas más arriba, y de la que la citaré más abajo, también la doctrina fue planteada en diversas resoluciones jurisdiccionales de la CCC. "Planteada", en este caso, significa que ha sido desarrollada por la CCC en la resolución jurisdiccional, con abstracción de su acogida con beneplácito o rechazo.

En un listado meramente ejemplificativo, menciono las siguientes sentencias: C-971, de 2004; C-986, de 2006; C-153, de 2007; C-427, de 2008; C-588, de 2009; C-574, de 2011; C-846, de 2012, C-010, de 2013, y recientemente la C-630, de 2017. La citación de la jurisprudencia, además del valor heurístico, quiere llamar la atención sobre una consistente continuidad en el desarrollo de la doctrina jurisdiccional.

La CCC, con diferentes integraciones, ha dado singulares pasos sobre esta cuestionable doctrina jurisdiccional. Obviamente, no es una doctrina "cerrada" 86 ni completa, porque la

86 Parra Dussan, Carlos: "Línea jurisprudencial sobre la sustitución constitucional", en AA.VV.: La sustitución de la Constitución: Un análisis teórico, jurisprudencia y comparado, Bogotá, Universidad Sergio Arboleda, 2015, pp. 141-171. 
elaboran los jueces de la CCC en el "cielo" de los conceptos abiertos, cuya producción reside en su propia voluntad discrecional.

He dejado para el final una de las sentencias más relevantes que se han pronunciado en la historia de la jurisdicción de la América del Sud ${ }^{87}$. La adjetivo como "relevante" con segura convicción, porque "equivocar la palabra es equivocar la cosa" 88 . Sin adelantar mi juicio, se trata de una sentencia que no se adecua al estatuto teórico planteado en este escrito. ¡Pese a ello, resulta escogida! No hace falta decirlo: en el decisorio jurisdiccional se hace aplicación de la doctrina de la sustitución por inconstitucionalidad.

La CCC, por mayoría, pronunció la sentencia C-141/10 ${ }^{89}$ (en adelante, "la sentencia"), por cuyo intermedio se resolvió "Declarar inexequible en su totalidad la Ley 1354 de 2009 'Por medio de la cual se convoca a un referendo constitucional y se somete a consideración del pueblo un proyecto de reforma constitucional'".

"La sentencia" terminó para siempre con las intenciones de reelección del presidente que, por entonces, ejercía la

87 La producción dogmática ha resultado muy extendida. V. CAJAS SARRIA, Mario Alberto: "Corte Constitucional dice no a segunda reelección presidencial en Colombia", en Namibia, Compromiso: Órgano Informativo del Poder Judicial de la Federación, 2010, pp. 44-45. Acuña Villaraga, Fabián Alejandro: “¿Presidentes desatados?: Reelección institucional y cambio en la Región andina", en Análisis político, nº 83, Bogotá, enero-abril de 2015, pp. 73-87; CharRía Segura, Juan Manuel: El referendo constitucional y la reelección presidencial, Bogotá, Universidad del Bosque, Pontificia Universidad Javeriana, Facultad de Ciencias Jurídicas, 2013; Ramírez PlazAS, Jaime: Seguridad democrática y reelección presidencial, Bogotá, Librería Ediciones del Profesional, 2012; VILA CASADO, Iván: "Al prohijar límites materiales implícitos al poder de reforma de la Constitución la Corte incrementa de manera injustificada y desproporcionada sus atribuciones", en Revista Elementos de juicio, Temas constitucionales, n 13, 2010.

88 SARTORI, Giovanni: La carrera hacia ninguna parte. Diez lecciones sobre nuestra sociedad en peligro, Buenos Aires, Taurus, 2016, p. 47.

89 Suscrita por los magistrados Mauricio González Cuervo (con salvamento de voto); María Victoria Calle Correa (con aclaración de voto); Juan Carlos Henao Pérez; Gabriel Eduardo Mendoza Martelo; Jorge Iván Palacio Palacio; Nilson Elías Pinilla Pinilla (con aclaración de voto); Jorge Ignacio Pretelt Chaljub (con salvamento de voto); Humberto Antonio Sierra Porto (con aclaración de voto) y Luis Ernesto Vargas Silva. Bogotá, D. C., 26 de febrero 2010. 
presidencia de la República ${ }^{90}$, encomienda constitucional que fenecía el 7 de agosto de 2010. Concluyentemente, pues, tal sentencia produjo que la jurisdicción constituida dispusiese la partida de defunción de un presidencialismo eterno.

En "la sentencia" siete jueces dijeron "no" a la segunda reelección de un presidente en "ejercicio y liderazgo del proceso político". Además, aplicaron la doctrina, cuyo texto y evolución aquí se amerita, e impidieron, con su decisión jurisdiccional, el ejercicio del "contenido más nuclear de la ciudadanía política" el sufragio.

Sin embargo, por esta vía, la jurisdicción quedó colocada como una fuente exclusiva de la normatividad del proceso político ciudadano en la comunidad. Pronunciarse en contra de "la sentencia" no significa estar a favor del presidencialismo ni estimular el absolutismo perpetuo. Tampoco significa maniatar a la jurisdicción constitucional en América del Sud.

La Constitución debe tener un protector: todos, ciudadanos y servidores públicos. No debería existir, en tal caso, una sociedad cerrada de realizadores de la Constitución. Una corporación no elegida en comicios abiertos por la ciudadanía y que, casi por la vía del absurdo o una omnipotencia unida a la omnisciencia, entiende que cuando un órgano (Congreso) carece de competencia para reformar la Ley fundamental, son ellos mismos (la CCC) los que tendrían competencia constitucional para formular un juicio sobre la habilitación jurídica del órgano congresual impugnado. Los jueces, con la doctrina de la sustitución, hacen ejercicio de una competencia de la que no disponen para afirmar que un órgano no disponía de competencias para realizar un acto constituyente. ¿La designación como magistrado de la CCC instituye al juez en el rol de sumo

\footnotetext{
90 Álvaro Uribe Vélez asumió su primera presidencia el 7/8/2002. Reelecto, asumió su segunda encomienda presidencial por otros cuatro años el 7/8/2006.

91 Aláez Corral, Benito: “Nacionalidad, ciudadanía y democracia en la configuración de la nación/pueblo", en Fundamentos. Cuadernos monográficos de Teoría del Estado, Derecho Público e Historia constitucional, nº 7, Oviedo, Junta General del Principado de Asturias, 2012, p. 88.
} 
pontífice de "competencias" sobre todas las "competencias del Estado"?

La fuente de autoridad de todo el poder del Estado reside en la ciudadanía, razón por la cual la última palabra no debería descansar en un órgano jurisdiccional, máxime cuando se trata del alcance de determinados derechos fundamentales; en el caso alumbrado en "la sentencia", sobre un referendo reformatorio de la Ley fundamental, el eminente derecho político ciudadano de sufragar. El consenso básico de los ciudadanos debería incluir la palabra de la jurisdicción, pero en el marco de un diálogo colectivo y jamás de manera excluyente. Simplemente, quiero apuntar que la construcción de una razón democrática plural y estable se garantiza con diálogos comunitarios y no con la dedicación de monólogos jurisdiccionales. Diálogos ciudadanos que, desde luego, no deben ser una "encuesta"92 ni una mera consulta de opinión, porque la expectativa yace en una ciudadanía robusta, activa e informada. La última palabra, en caso de que las existencias humanas puedan edificarla, debería prosperar del conjunto de los ciudadanos, en el ámbito de un auditorio inclusivo, sustentable y deliberativo de la discusión pública. Al fin y al cabo, son sus existencias vitales ${ }^{93}$.

\section{$\S$ V. Comentarios finales}

Primero. Casi 230 años más tarde, las escrituras del Derecho constitucional en América del Sud persiguen la realización del elixir, quizá inalcanzable, redactado en el artículo 16 de la DDHC, 1789: "Una sociedad en la que la garantía de los derechos no está asegurada, ni la separación de poderes determinada, no tiene constitución". Para asegurar la existencia de los seres humanos hay que acordar la paz; el único ámbito que favorece

92 Gargarella, Roberto: "Reivindicación de los plebiscitos", El País, 10/2/2017, disponible en https://elpais.com/elpais/2017/02/09/opinion/1486644995_314713.html, consultado por última vez el 25/5/2018.

93 CLARK, Brian: Whose life is it anyway?, Heinemann, Essex, 1993. 
el desarrollo de una mutualidad beneficiosa de todos sujetos naturales, porque sólo así ellos podrán desarrollar y conservar sus vidas. La Constitución, fundamento del Estado, debe tener como fin mínimo la realización de la paz, porque ella se yergue en condición necesaria para cualquier objetivo: libertad, igualdad o fraternidad. Los seres humanos deben alcanzar consensos estables y robustos sobre la coexistencia comunitaria. De ello se derivará una necesaria asignación de la gobernanza, en la que unas personas deberán gobernar, cuyo significado implica que no incurran en comportamientos arbitrarios, corruptos, o respondan a estrategias colonialistas, y otras personas serán gobernadas, cuya implicación más directa debería impedir que se arrodillen, encojan o se callen y que se encuentren preparadas y dispuestas para llevar adelante los negocios comunitarios, si lo desean y pueden algún día.

Segundo. La distinción entre derechos del hombre y derechos de ciudadano resulta determinada por el Derecho constitucional positivo. En rigor, ambas entidades encierran una endíadis (derechos fundamentales). Esto es así porque el hombre, en tanto posible y seguro ciudadano, es el único sujeto que, en la congregación de individualidades con sus semejantes, puede crear el Estado y su fundamento noble: la Constitución.

Tercero. El poder constituyente para instaurar un orden jurídico soberano depende de una ciudadanía, esto es, el conjunto de los ciudadanos que integran el pueblo. El ente estatal y su fundamento -el bien colectivo "Constitución"- son constituidos por personas humanas, que más tarde, como ciudadanos, deben activarlos, desarrollarlos y transformarlos. El ciudadano, así, es una especie del género persona, ser humano o persona natural. Los órdenes jurídicos modernos caracterizan, por lo general, a la ciudadanía por la atribución de los derechos políticos y los deberes correlativos. La ciudadanía puede ser comprendida desde su titularidad o desde la estructura de los derechos y deberes que se disponen en su contenido.

Cuarto. La titularidad de la ciudadanía instituye entre los hombres que disfrutan de ella de una "igualdad fundamental 
de pertenencia"94 a una determinada comunidad; así, todos los ciudadanos son exactamente iguales en derechos y deberes. La ciudadanía pone al descubierto la "capacidad de participación del individuo como miembro de pleno derecho"95 del Estado al que se encuentra sometido y en cuya construcción y sostén del orden jurídico ha de ser incluido.

Quinto. Desde la comprensión de su estructura, la ciudadanía queda ligada a la estructura de los derechos y deberes que puede desarrollar; de este modo, se vislumbra la soberanía inherente de cada individuo que, en tanto ciudadano, dispondrá de un poder mínimo, pero poder al fin, para deliberar, impulsar y decidir la ordenación y desarrollo de la comunidad en que existe. Las Constituciones, al universalizar el derecho al sufragio de todos los ciudadanos y generar modelos de democracia participativa directa, trazan un recorrido hacia la igualdad, que no amortigua la desigualdad social, pero al menos, al configurar las bases de una ciudadanía bastante igualitaria, significan un paso adelante, nunca hacia atrás, en la construcción política de la comunidad.

Si bien la ciudadanía no hará desaparecer las clases sociales, su extensión en los individuos que integran la sociedad política puede ser uno de los remedios (no el único, jamás) para aliviar la intolerable injusticia social que existe en todos los países de América del Sud.

Sexto. Las personas humanas -en tanto ciudadanos, que son los artífices- y el Derecho constitucional -que resulta ser el artificio- se corresponden, siempre, en una relación única e inmodificable, en la que se afirma la tesis que atribuye el papel "constituyente", creador, autoral, de los sujetos naturales que está en el origen de todo el Derecho constituyente del Estado. Una vez instaurada la Constitución del Estado, su protocolo determinará las etapas distinguidas del proceso de su reforma.

94 Marshall, Thomas Humphrey: "Ciudadanía y clase social", Revista Española de Investigaciones sociológicas, $n^{0}$ 79, Madrid, 1997, p. 301.

95 Aláez Corral, Benito: “Nacionalidad, ciudadanía y democracia..., ob. cit., p. 96. 
Así, el cambio de la Ley Mayor, con su obligatorio proceso, arraiga la certeza del propio orden jurídico y se convierte en fundamento del Estado.

El máximo poder jurídico de configuración de la realidad, se trate de la fundación constitucional o de su variación, reside en la ciudadanía, la que por regla actúa gracias a la mediación de sus representantes; aunque existen ocasiones en que tanto el acto constituyente originario como su reforma pueden ser discernidas directamente al cuerpo electoral.

Séptimo. La Constitución colombiana de 1991 define con claridad que los ciudadanos, sea en forma directa, sea por la vía de la representación política, son quienes deben ejercer la "dirección suprema" de la totalidad de la ordenación de las existencias en el Estado. Esos ciudadanos, por regla, en el juego enhebrado por la Ley fundamental, siempre tendrán ideas o concepciones diferentes sobre el pasado, el presente y el futuro ${ }^{96}$, por aquello de que la realidad mundana existe objetiva e independientemente del designio y conocimiento de los humanos ${ }^{97}$. Dentro de tal comprensión, el ciudadano, en la conjugación de sus derechos y deberes, queda instituido en su rol protagónico, desde que a cada uno de ellos se le debe asignar igual participación en la producción del escenario constitucional del Estado. Ciertamente, no hay ciudadanía si hay desinformación u orden cerrado. Tampoco podrá existir la ciudadanía si el hombre carece de la posibilidad de satisfacer las necesidades básicas de alimentación y conservación de él y su familia. Como se ha referido, el ciudadano es el átomo de

\footnotetext{
96 Arthur Schopenhauer, en 1819, estimó que ningún ser humano vivió en el pasado y ningún hombre vivirá en el futuro, sino que "que únicamente el presente es la forma de toda vida, pero es también su posesión segura que nunca se le puede arrebatar". Entendido el pasado como un momento en que el ser humano no existió y el futuro como un momento en el que no existirá, la afirmación tiene bases materialistas de certidumbre definitivamente irreprochables e indiscutidas. V. SchopenHAuer, Arthur: El mundo como representación y voluntad, t. I, Madrid, Trotta, 2016, p. 334.

97 RusselL, Bertrand: "El realismo analítico", en Análisis filosófico, Buenos Aires, Paidós, 1999, p. 66.
} 
la comunidad política, cuya pequeñez es "extremada", pero su condición es "indivisible".

Octavo. Los hombres han dedicado y destinado largos años a aprender y disfrutar de las ventajas que puede proporcionar, en general, una ordenación jurídica determinada; calificada por la primacía de una norma que se erige como superior, con jerarquía intransigente, indubitable e indisputable por encima del resto de las normas que integran el sistema jurídico estatal y se califican como inferiores. La configuración de reglas sobre el Derecho constituyente del Estado ha contenido en su escritura -casi siempre- una regla suprema, es decir, la Constitución como norma que fundamenta la totalidad del orden jurídico, “... tanto por su forma de creación, cuanto por su contenido" 98 .

Dentro del marco de la Ley fundamental, la mayoría de las decisiones de relevancia que hacen a la gobernanza -por no decir casi la totalidad- las adoptan los servidores públicos. No existe el mandato imperativo. Así, en la Constitución colombiana de 1991, por ejemplo, hay una norma, que aunque emplazada en el artículo 133, Título vi, "Rama Legislativa", según mi leal saber y entender, debería adjudicarse a todos los servidores públicos:

Los miembros de cuerpos colegiados de elección directa representan al pueblo, y deberán actuar consultando la justicia y el bien común. El elegido es responsable políticamente ante la sociedad y frente a sus electores del cumplimiento de las obligaciones propias de su investidura.

Frente a esta circunstancia, la extensión de la ciudadanía debería tornarse una actividad casi obligatoria, porque cada ciudadano tendrá responsabilidad "en las decisiones que lo afectan y en la vida económica, política, administrativa y cultural” del Estado, como se alumbra en el artículo 2 de la CPC 1991.

Noveno. Toda Constitución debería autorizar un solo lenguaje posible y acudir, así, a un modelo autorreferente. El propio

\footnotetext{
98 V. Bidart Campos, Germán J.: El Derecho de la Constitución y su fuerza normativa, Buenos Aires, Ediar, 1995, p. 92.
} 
proceso de su cambio jurídico formaliza, sin temores, que la Constitución puede ser reformada, con el debido respeto de sus determinaciones precisas, que nunca pueden ser entendidas como frutos inmaduros o prescripciones inútiles.

La Constitución no es un tesoro intacto y secreto. Al encontrarse en el mundo, como objeto tecnológico o hechura propia del ser humano, se encuentra sometida a la posibilidad de su derrotero y de su propio cambio político. Tampoco sus letras deben ser consideradas sigilosas, porque, precisamente, la Constitución articula, muchas veces con alegoría superflua y otras con rigurosa sobriedad, la palabra pública, la lengua para la ordenación de la vida de los ciudadanos en la comunidad estatal.

Constitución y reforma son ideas inseparables, desde que la primera no puede concebirse con naturaleza sempiterna y la segunda es inseparable de la propia vocación de progreso de la especie humana. Una reforma constitucional es la que produce un cambio en el contenido del orden jurídico estatal, pero no produce la destrucción del preexistente, si mantiene la continuidad por la vía de su adaptación o desarrollo de nuevos esquemas jurídicos. Por eso, la función constituyente (creación o variación del Derecho constitucional) debe imputarse a los representantes de los ciudadanos.

El momento de la creación constitucional, es decir, el momento del alumbramiento de las pautas originarias que determinan la convivencia política de una sociedad requiere un debate cuya libertad, amplitud, profundidad, serenidad y consenso parecieran sólo garantizados por la emanación democrática de los ciudadanos del pueblo. En otras palabras, en estos "momentos constituyentes" lo que pareciera que verdaderamente se debería afirmar es la democracia como modelo de orientación política del Estado, bajo la forma de gobierno de una república, que asegura las existencias de todos los individuos.

La Constitución de Colombia de 1991 dispone de tres procesos singulares para reformarse: a instancias del Congreso, promocionado por los ciudadanos por la vía del referendo, o mediante una 
Asamblea Constituyente. Sin ingenuidad, repito, que la vía del referendo constituye un mecanismo extremadamente interesante para el Derecho constitucional en América del Sud.

Décimo. En dos de los modelos, referendo y Asamblea Constituyente, la Corte Constitucional de Colombia, a la sazón órgano constituido, intervendrá en el curso mismo del proceso reformador de la Ley fundamental. Su actuación, en tales situaciones, se contempla para distinguir, previamente, "vicios de procedimiento en su formación" (art. 241, inc. 2). Además, en el artículo 379 se prescribe lo siguiente:

Los Actos Legislativos, la convocatoria a referendo, la consulta popular o el acto de convocación de la Asamblea Constituyente, sólo podrán ser declarados inconstitucionales cuando se violen los requisitos establecidos en este título. La acción pública contra estos actos sólo procederá dentro del año siguiente a su promulgación...

La posible o segura presencia de la Corte Constitucional de Colombia en el proceso reformador significa un modelo en América del Sud. Dentro de la cultura jurídico constitucional colombiana será imposible que una reforma de la suma regla no fuese, finalmente, susceptible de ser enjuiciada en la jurisdicción constitucional. El enjuiciamiento jurisdiccional de la reforma constitucional, aunque no es una curiosidad en el Derecho comparado, tampoco se presenta cotidianamente. Todo juicio de esta naturaleza encierra dos cuestiones: una, que se trata del máximo vicio que se podría representar dentro de un orden jurídico; dos, la problemática delicadísima de cuál ha de ser el órgano del Estado encargado de remediar la patología.

Para responder quedamos sometidos, en el caso colombiano, a la irredimible obligatoriedad de su orden constitucional. Sin embargo, en la lengua de este escrito, planteo un duelo permanente con dicha definición constitucional. Si el lenguaje constitucional debe ser constituido de abajo hacia arriba por cada uno de los ciudadanos, la intervención jurisdiccional mencionada nos aleja de ese modelo constituyente. Más que un diálogo, pareciera instituir una supremacía monologada de la 
jurisdicción. Tampoco me anima, desde luego, la divinización de la ciudadanía. Lo que me preocupa es que un poder constituido, no elegido directamente por los ciudadanos, adopte decisiones sobre la constitucionalidad de las existencias ciudadanas en la comunidad, cuyo modo de agregación de las preferencias -la suma de las razones de los jueces- no sólo no es un criterio científicamente objetivado, sino que es similar al político de los congresistas o al propio sufragio de los ciudadanos.

Este escrito llega a su fin. Decir que hay una cultura colombiana que emana de su Ley fundamental originaria de 1991, con sus letras esenciales referidas a su "pueblo", a la propia "norma" y a sus procesos de "cambio", constituye una afirmación que posee rasgos propios y que son suficientes para definirla y demarcarla en su globalidad. La descripción y la justificación que se hacen en este texto han procurado, en todo cuanto ha sido posible de buena fe, presentar a la República de Colombia "fundada" por su Ley mayor de 1991.

Me complacerá pensar, por lo pronto, que el lector encontrará debidamente justificada la tesis primitiva anunciada en la sección I, en cuanto concierne a la estrategia montada en la sección II. Esta tarea ha quedado ceñida, con exclusividad, al análisis dogmático sobre las letras constitucionales de 1991. Una tarea cumplida por un hombre que no es colombiano ${ }^{99}$, porque ha nacido en otra "provincia" de América del Sud.

El hombre requiere de un lenguaje para ejercer cierto dominio sobre la realidad; porque la composición, armonía y gramática de las palabras puede comportarse como un agente para la creación, el mantenimiento o el cambio de las existencias humanas. Hablar de una lengua del Derecho constitucional tiene sentido, dado que para lograr que rijan o que tengan eficacia los enunciados de la lengua constituyente del Estado, los hombres deben comprenderse en la escena del

99 ¿La existencia de los humanos, en una comunidad, cambiará el día en que fuese posible elegir el territorio en el que desearían nacer y, al mismo tiempo, quiénes serían sus padres biológicos? 
dominio lingüístico y están obligados a producir una asociación recurrente, intensa y prolongada sobre las determinaciones prescriptivas de la conducta humana. Las escrituras constitucionales -con sus variaciones- siempre han de incluir la lengua de los seres humanos que han muerto, junto a la lengua de los seres vivos, quienes deben actuar con serena responsabilidad respecto de aquéllos, de ellos mismos y de las personas por nacer. En tales condiciones, pareciera que la Constitución fuese un objeto milagroso de las existencias, aunque -reitero- no lo es ni debe serlo. Por todo ello, la lengua del Derecho constitucional aquí descrita guarda la esperanza de que otros hombres de nuestras tierras prosigan, con otros textos, el desarrollo de su deliberación y escritura infinita. ${ }^{100}$

\footnotetext{
${ }^{100}$ Agradezco a los juristas de Colombia, con quienes he tenido el placer dialogar sobre una 0 varias de las argumentaciones dogmáticas desarrolladas en el escrito. Ellos son: Alfonso Clavijo González, Carolina Valencia Mosquera, César Domínguez, Manuel Salvador Grosso, John M. Ferrer Murillo, Vanessa Pérez Rosales, Andrés Pérez Velasco, Giovanni Alvarez Cruz, Luis Manuel Lasso Lozano, Jaime Becerra, Juan H. Arévalo Tovar, Gloria L. Arango Pajón, José V. Andrade, Jesús Fuentes, Claudia V. Valderrama Bejarano, Camilo J. David Hoyos, Carlos A. Ramírez, Leonardo Sabogal, Edgar Fuentes Contreras y Ana Carolina Molina. También he conversado, razón por la cual agradezco, con los juristas E. Raúl Zaffaroni, Julio B. J. Maier, Ricardo Rabinovich-Berkman, Luciano Vernetti, Pablo O. Cabral, Guillermo Moreno, Diego A. Dolabjian, Enrique Morales, Leandro E. Ferreyra y Natasha Suñe (Argentina); Paulo Bonavides; Rodrigo Visotto Junkes, Vera Lazar C. y Adriana do Carmo Figuereido (Brasil); Gonzalo Hidalgo N. (Bolivia); Alfonso Celotto (Italia); Benito Alaez Corral (España); Pablo Gres y Alvaro Fuentealba (Chile), Ernesto Velázquez y Gabriel Rivera (Ecuador) y Diego Valadés (México).
} 